Mitchell Hamline School of Law

Masthead Logo Mitchell Hamline Open Access

Faculty Scholarship

2017

\title{
The Commodification of Trademarks: Some Final Thoughts on Trademark Dilution
}

Kenneth L. Port

Mitchell Hamline School of Law, ken.port@mitchellhamline.edu

Publication Information

46 Hofstra Law Review 669 (2017)

\section{Repository Citation}

Port, Kenneth L., "The Commodification of Trademarks: Some Final Thoughts on Trademark Dilution" (2017). Faculty Scholarship. 458.

https://open.mitchellhamline.edu/facsch/458 


\title{
The Commodification of Trademarks: Some Final Thoughts on Trademark Dilution
}

\begin{abstract}
This article is an explication of the trend toward commodification of famous or putatively famous trademarks and the resultant urging that the FTDA be repealed. This article starts with a literature review showing that the vast majority of commentators have been severely critical of the FTDA. This has been ignored by Congress. The article next pursues Congress's blind support of the FTDA and suggests that more thought and analysis from Congress is still required. The article next explains the data regarding FTDA claims. All reported cases from 1996 through 2015 are coded and examined. The conclusion, looking at the data, is that the FTDA cause of action is going away. It has been rarely used in enforcement actions, it is much less likely to be successful than other trademark litigation, and the downward trend of enforcement continues. Finally, the article considers commodification of trademarks and how we are all negatively impacted by it.
\end{abstract}

\section{Keywords}

Trademarks, Trademark dilution, Commodification, Federal Trademark Dilution Act, Lanham Act

\section{Disciplines}

Intellectual Property Law 


\title{
THE COMMODIFICATION OF TRADEMARKS: SOME FINAL THOUGHTS ON TRADEMARK DILUTION
}

\author{
Kenneth L. Port*
}

\section{INTRODUCTION}

The Federal Trademark Dilution Act of 1995 ("FTDA") has not been the panacea for famous marks it was intended to be and has created perverse unintended consequences. Academics (including myself) have pointed out for years that the FTDA is unconstitutional ${ }^{2}$ as it creates rights under the Lanham $\mathrm{Act}^{3}$ instead of codifying the common law, the express purpose of the Lanham Act. ${ }^{4}$ In addition, Congress may regulate trademark law in the United States by relying on the Commerce Clause of the United States Constitution. ${ }^{5}$ However, as the FTDA allows for the protection of trademarks distinct from the commerce on which they are used, dilution is arguably unconstitutional.

The best way to make sense of the FTDA is to concede that the Lanham Act's FTDA provisions create a property right in a famous trademark. ${ }^{6}$ United States trademark jurisprudence generally does not

* Professor of Law and Director, Intellectual Property Institute, William Mitchell College of Law. I thank Anna Harper, J.D. Candidate, 2018 for her expert research assistance.

1. Pub. L. No. 104-98, 109 Stat. 985 (codified in 15 U.S.C. $\$ \$ 1125,1127(2000)$ ), amended by Trademark Dilution Revision Act of 2006, Pub. L. No. 109-312, 120 Stat. 1730 (codified as amended in 15 U.S.C. $\$ \$ 1052,1063,1064,1092,1125,1127(2006))$.

2. See, e.g., Kristan Friday, Does Dilution Make Trademarks into Unconstitutional Patents?, 12 J. Contemp. Legal Issues 180, 183 (2001); Brian A. Jacobs, Trademark Dilution on the Constitutional Edge, 104 Colum. L. REv. 161, 173-75 (2004); Robert N. Klieger, Trademark Dilution: The Whittling away of the Rational Basis for Trademark Protection, 58 U. PITT. L. REV. 789, 841 (1997).

3. Lanham (Trademark) Act, Pub. L. No. 79-489, 60 Stat, 427 (1946) (codified in scattered sections of 15 U.S.C.).

4. See Robert C. Denicola, Some Thoughts on the Dynamics of Federal Trademark Legislation and the Trademark Dilution Act of 1995, LAW \& CONTEMP. PROBS., Spring 1996, at 75, $79-80$.

5. U.S. CONST. art. I, $\S 8, \mathrm{cl} .3$.

6. See Kenneth L. Port, The Congressional Expansion of American Trademark Law: A Civil 
recognize the trademark as subject to property ownership. ${ }^{7}$ In addition, this property right in famous marks subject to the FTDA is considered absolute even though property rights have never been absolute in the United States. ${ }^{8}$ Furthermore, the trademark itself has never been subject to property ownership. The trademark right lacks incidents of ownership to make it subject to property ownership. ${ }^{9}$ As such, when the FTDA allows property ownership in a mark, it is inconsistent with all prior common law on the topic. Therefore, courts have struggled mightily to apply the FTDA in a sane and rational manner. ${ }^{10}$

Reported litigation involving the FTDA in the United States has all but ceased. ${ }^{11}$ Reported cases demonstrate that the FTDA is not a popular cause of action. When the FTDA was enacted, we were told that there was a huge harm going unrectified in the trademark world. ${ }^{12}$ We were

Law System in the Making, 35 WAKE FOREST L. REV. 827, 875-76 (2000).

7. See, e.g., Viacom Inc. v. Ingram Enters. 141 F.3d 886, 892 (8th Cir. 1998) (holding that to grant plaintiff's dilution claim would constitute a monopoly on the use of language in commerce); Mister Donut of Am., Inc. v. Mr. Donut, Inc., 418 F.2d 838, 842 (9th Cir. 1969) ("The law is well settled that there are no rights in a trademark alone ...."); see also Kenneth L. Port, The Illegitimacy of Trademark Incontestability, 26 IND. L. REV. 519, 552-68 (1993).

8. See, e.g., United Drug Co. v. Theodore Rectanus Co., 248 U.S. 90,97 (1918) "There is no such thing as property in a trade-mark except as a right appurtenant to an established business or trade in connection with which the mark is employed."); ITC Ltd. v. Punchgini, Inc., 482 F.3d 135, 146-47 (2d Cir. 2007); Electro Source, LLC v. Brandess-Kalt-Aetna Grp., Inc., 458 F.3d 931, 939 n.7 (9th Cir. 2006); Mid-List Press v. Nora, 374 F.3d 690, 693 (8th Cir. 2004); see also Festo Corp. v. Shoketsu Kinzoku Kogyo Kabushiki Co,, 535 U.S. 722, 730 (2002) ("The monopoly is a property right; and like any property right, its boundaries should be clear."); Palazzolo v. Rhode Island, 533 U.S. 606,627 (2001) (finding the right to improve property is subject to the exercise of reasonable state authority); Tooahnippah v. Hickel, 397 U.S. 598, 609 (1970) (finding that property rights in government allotments are not absolute); United States v. Taylor, 8 F.3d 1074, 1077 (6th Cir. 1993) (finding the right to refuse entry to land is not absolute); In re Farmers Mkts., Inc., 792 F.2d 1400 , 1403 (9th Cir. 1986) ("Property rights are not absolute."); United States v. 16.92 Acres of Land, 670 F.2d 1369, 1373 (7th Cir. 1982) ("It is axiomatic that property rights are not absolute ...."); Ill. Migrant Council v. Campbell Soup Co., 574 F.2d 374, 379 (7th Cir. 1978) ("[P]roperty rights are not absolute...."); Glynn S. Lunney, Jr., Trademark Monopolies, 48 EMORY L.J. 367, 372-73 (1999) (pointing out that trademark expansion from deception-based to property-based trademark paradigm "presents a serious threat to social welfare").

9. See Port, supra note 6, at 552-68.

10. See, e.g., Mead Data Cent., Inc. v. Toyota Motor Sales, U.S.A., Ine., 875 F.2d 1026. 1030-31 (2d Cir. 1989) (finding that the appropriate population for finding similarity is the reified television announcer but the appropriate population to find fame is society at large); see also ANNE Gilson laLonde et al, 2 Gilson on TRAdemarks: Trademark Protection and PRActice 5A-42 (2006) ("[J]udges dislike dilution law and construe it as narrowly as possible.").

11. See infra notes $136-41$ and accompanying text.

12. The Committee on the Judiciary reported:

The concept of dilution recognizes the substantial investment the owner has made in the mark and the commercial value and aura of the mark itself, protecting both from those who would appropriate the mark for their own gain.

A federal dilution statute is necessary because famous marks ordinarily are used on a nationwide basis and dilution protection is currently only available on a patch-quilt 
told that the dilution of trademarks would result in "a cancer-like growth of dissimilar products or services which feeds upon the business reputation of an established distinctive trade-mark or name." 3 We were told that there was a fearsome "gap" in trademark protection and unless we protected famous marks from dilution, the trademark house of cards would implode ${ }^{14}$ However, as there are, today, very few cases reported that rely exclusively on the FTDA, ${ }^{15}$ it is safe to say that this so-called harm never materialized or, if it exists, has not been deemed important enough to be manifested in reported cases.

Perhaps the best critique and explanation of some of the early conundrums regarding dilution was supplied by Judge Matthew J. Jasen in the Allied Maintenance Corp. case as follows:

Generally, courts which have had the opportunity to interpret an anti-dilution statute have refused to apply its provisions literally. New York courts, State and Federal, have read into the statute a requirement of some showing of confusion, fraud or deception.

Judicial hesitance to enforce the literal terms of the anti-dilution statute has not been limited to New York. In Illinois, for example, some courts have gone so far as to declare the statute inapplicable where the parties are competitors and a likelihood of confusion does exist. These decisions were premised upon the belief that a plaintiff who can frame his complaint under a theory of infringement or unfair competition-albeit unsuccessfully perhaps-should not succeed under a dilution theory. However, one court in Illinois has interpreted the anti-dilution statute literally, reasoning that unless recovery for dilution is permitted in the absence of competition or confusion the statute adds nothing to existing law. ${ }^{16}$

One could presume that the FTDA has been a net positive for trademark plaintiffs' attorneys because it provides another basis on which to sue, file claims, and counsel clients. ${ }^{17}$ However, as the parameters of "fame" (required under the FTDA) are so nebulous, ${ }^{18}$ it

system of protection, in that only approximately 25 states have laws that prohibit trademark dilution.

H.R. REP. NO. 104-374, at 3 (1995).

13. Allied Maint. Corp. v. Allied Mech. Trades, Inc. 369 N.E.2d 1162, 1165 (N.Y. 1977).

14. Schechter, in his famous article, argued that "the gradual whittling away or dispersion of the identity and hold upon the public mind of the mark or name by its use upon non-competing goods" was not addressed by the Lanham Act, and would lead to Rolls-Royce radios, Kodak bicycles, and Beech-Nut cigarettes. Frank I. Schechter, The Rational Basis of Trademark Protection, 40 HARV. L. REV 813,825 (1927).

15. See infra notes $138-39$ and accompanying text.

16. Allied Main. Corp. 369 N.E.2d at 1165 (citations omitted).

17. See infia note 135 and accompanying text.

18. Congress left the final definition of "fame" up to the courts, when it included a non- 
has, in fact, created much uncertainty about the scope of any trademark. ${ }^{19}$ Truly famous and not famous marks alike claim to be famous for purposes of the FTDA. The uncertainty regarding fame detracts from the predictability of any trademark cause of action and, therefore, actually detracts from a rational litigant's desire to incur the cost of trademark dilution litigation and file suit. Perhaps this is why there is almost no reported litigation regarding the FTDA today. ${ }^{20}$

This uncertainty has encouraged trademark holders ${ }^{21}$ to engage in speculation (also known as trademark extortion or trademark bullying). ${ }^{22}$ Trademark holders feel compelled to make spurious claims that their marks are famous and therefore a justifiable cause of action under the FTDA. ${ }^{23}$ The FTDA has encouraged trademark holders to see their trademark rights as a mere commodity, the value of which can be enhanced to the extent that people acquiesce to spurious claims of fame or spurious claims that are perceived as leading to fame of their trademark. ${ }^{24}$ It is a good and appropriate thing that trademark holders have come to view their trademarks as an asset. ${ }^{25}$ However, when the

exclusive list of factors in the FTDA. Sce 15 U.S.C. $\$ 1125(\mathrm{c})(2)(\mathrm{A})(2012)$. The courts have moved from using factors that widen the definition of fame (regional fame, niche markets) to those that make fame harder to establish. See Clarisa Long, Dilution, 106 Colum. L. REv. 1029, 1071-72 (2006).

19. See David J. Franklyn, Debunking Dilution Doctrine: Toward a Coherent Theory of the Anti-Free-Rider Principle in American Trademark Law, 56 HASTINGS L.J. 117, 129-31 (2004).

20. See infia notes $138-39$ and accompanying text.

21. Rather than "owners," I refer to the entity who claims a trademark to be the "holder" of the mark. "Owner" contributes to the unjustifiable rhetoric that a trademark is subject to property ownership when it is not. The right to exclude others from using the same or similar mark on the same or similar products is a property right; however, the mark itself is never subject to property ownership. Dilution, of course, changes this calculus. Dilution subjects the mark to near absolute ownership; however, as this so-called ownership was never contemplated by the Commerce Clause or the Lanham Act, I prefer using the appropriate term to describe what a trademark claimant does: holding rather than owning.

22. Trademark extortion or bullying is the practice of "a trademark holder assert[ing] a nonfamous mark against a non-competing entity [or entities] on or in connection with goods or services into which the plaintiff has no reasonable expectation of expanding." Kenneth L. Port, Trademark Extortion Revisited: A Response to Vogel and Schachter, 14 CHI.-KENT J. INTELL. PROP. 217.221 (2014).

23. See id. at 226-32. The rate of summary judgment for defendants in trademark cases rose to $5.5 \%$ of cases in 2009 . Id . at $226 \&$ tbl. 1 .

24. Borghese Trademarks Inc. v. Borghese, No. 10 CIV. 5552(JPO)(AJP), 2013 WL 143807, at *14-16 (S.D.N.Y. Jan. 14, 2013) (bringing cause of action against members of the Borghese family claiming, in part, that use of their actual name on noncompeting goods amounted to trademark infringement).

25. Perhaps the most extreme expression of this is a book titled The Physics of Brand: Understand the Forces Behind Brands that Matter. AARON KELLER ET AL., THE PHYSICS OF BRAND: UNDERSTAND THE FORCES BEHIND BRANDS THAT MATTER (2016). The authors of this book have skillfully expressed the idea of brand management as if it were a science. In order to develop a mark that "matters" (according to the authors), one apparently follows the scientific steps 
source identifying function of a trademark has no rational relationship to whether a trademark is asserted against a third party, the balance between using the trademark as a source identifier and the mere enforcement of trademark for perceived financial gain leads to the commodification of trademarks. This is not what the United States Constitution, the Lanham Act, or the common law upon which it is based, allows. ${ }^{26}$

The commodification of trademarks has led American trademark holders away from seeing the mark as an indicator of source and into seeing the trademark exclusively as a commodity upon which returns can be recognized. The conceptual challenge here is that the FTDA encourages trademark holders to see their trademark as a commodity to be bought and sold like any other commodity and encourages them to forget the first principle in trademark jurisprudence: the mark is first an indicia of source ${ }^{27}$ and is nothing when used other than appurtenant to the goodwill associated with that mark. ${ }^{28}$ As a commodity, trademark

that the authors proscribe. $I d$. at 12-16, 13 fig.1.1, 14 fig.1.2, 15 fig.1.3.

26. Secretary of State Thomas Jefferson properly saw that the rights of a trademark should fall under the Commerce Clause. See Thomas Jefferson. Report on the Policy of Securing Particular Marks to Manffacturers, by Law, in 3 THE WRITINGS OF THOMAS JIFFERSON 156, 157 (Andrew A. Lipscomb \& Albert Ellery Bergh eds., 1905) (stating that Jefferson limited any trademark law to "commerce with foreign nations, and among the several States, and with the Indian Tribes," tracking the Commerce Clause verbatim); Kenneth L. Port, Trademark Extortion: The End of Trademark Law, 65 WASH. \& LEE L. REV. 585, 593 (2008). His wisdom was not realized until after the failure of trademark law to take hold under the copyright and patent provision. See Port, supra at 593-96. The Lanham Act was enacted to selectively codify the common law in order to provide consistent protection of a trademark on a national scale, according to the Supreme Court's interpretation of the congressional record:

Congress enacted the Lanham Act in 1946 in order to provide national protection for trademarks used in interstate and foreign commerce... Previous federal legislation, such as the Federal Trademark Act of 1905 ... reflected the view that protection of trademarks was a matter of state concern and that the right to a mark depended solely on the common law.... Consequently, rights to trademarks were uncertain and subject to variation in different parts of the country. Because trademarks desirably promote competition and the maintenance of product quality, Congress determined that "a sound public policy requires that trademarks should receive nationally the greatest protection that can be given them."

Park 'N Fly, Inc. v. Dollar Park \& Fly, Inc., 469 U.S. 189, 193 (1985) (first citing S. REP. No. 791333 , at 5 (1946); and then quoting $i d$. at 6).

27. See Kidd v. Johnson. 100 U.S. 617,620 (1879) (finding that "the primary object of a trade-mark is to indicate by its meaning or association the origin of the article to which it is affixed" and that such trademark cannot be the subject of a sale, separate from the sale of a business); see also Two Pesos, Inc. v. Taco Cabana, Inc., 505 U.S. 763. 786 (1992) (Thomas. J.. concurring) (stating that common law presumed a trademark was the indicator of source); In re Tam, 808 F.3d 1321, 1345 (Fed. Cir. 2015) (finding a trademark identifies the source of the goods and its purpose is to identify said source), cert granted sub nom. Lee v. Tam, 137 S. Ct. 30 (2016), aff'd sub nom. Matal v. Tam, 137 S. Ct. 1744 (2017).

28. See infra notes $41-42$ and accompanying text. 
holders perceive a gain by speculating on the underlying value of the trademark devoid of its functioning to identify source. ${ }^{29}$ This leads us far afield from the original intent of congressional protection of trademarks.

This Article is an explication of the trend toward commodification of famous or putatively famous trademarks and the resultant urging that the FTDA be repealed. This Article starts with a literature review showing that the vast majority of commentators have been severely critical of the FTDA. ${ }^{30}$ This has been ignored by Congress. The Article next pursues Congress's blind support of the FTDA and suggests that more thought and analysis from Congress is still required. ${ }^{31}$ The Article next explains the data regarding FTDA claims. ${ }^{32}$ All reported cases from 1996 through 2015 are coded and examined. ${ }^{33}$ The conclusion, looking at the data, is that the FTDA cause of action is going away. ${ }^{34}$ It has been rarely used in enforcement actions, it is much less likely to be successful than other trademark litigation, and the downward trend of enforcement continues. Finally, the Article considers commodification of trademarks and how we are all negatively impacted by it. ${ }^{35}$

\section{NO TRADEMARK RIGHTS IN GROSS}

Historically, trademark rights have not been an in gross right in the United States. ${ }^{36}$ Since 1996, trademark dilution rights under the FTDA have been granted in gross. ${ }^{37}$ This may be the precise reason why there

29. Of course, as a commodity, the trademark has been valued in other contexts such as for purposes of the Securities and Exchange Commission, etc. However, these purposes are external from trademark jurisprudence. Also, although there is nothing normatively wrong with the commodification of trademarks, if we are to commodify trademarks within trademark jurisprudence, it ought to be done intentionally not as an unintended after effect to the FTDA.

30. See infra Part III.

31. See infra Part IV.

32. See infra Part $\mathrm{V}$.

33. See infra notes $136-38$ and accompanying text.

34. This is inconsistent with INTA's predictions that we would see more cases involving dilution. See Marie Driscoll, INTA and United States Courts, 93 TRADLMARK REP. 128, 133 (2003).

35. See infra Part VI.

36. See Beanstalk Grp., Inc. v. AM Gen. Corp., 283 F.3d 856, 861 (7th Cir. 2002) ("[A] trademark is an identifier, not a freestanding piece of intellectual property; hence the rule that a trademark cannot be sold in gross, that is, without the assets that create the product that it identifies."); Marshak v. Green, 746 F.2d 927, 929 (2d Cir. 1984) ("A trade name or mark is merely a symbol of goodwill; it has no independent significance apart from the goodwill it symbolizes.").

37. 15 U.S.C. $\$ 1125(\mathrm{c})(1)$ states:

Subject to the principles of equity, the owner of a famous mark that is distinctive, inherently or through acquired distinctiveness, shall be entitled to an injunction against another person who, at any time after the owner's mark has become famous, commences use of a mark or trade name in commerce that is likely to cause dilution by blurring or dilution by tamishment of the famous mark, regardless of the presence or absence of actual or likely confusion, of competition, or of actual economic injury. 
is a judicial reticence to apply the FTDA as it seems to be intended in any given case. ${ }^{38}$ That is, courts apparently do not believe the statute as written and struggle mightily to apply some brakes.

When considering the FTDA and famous marks under it and all other trademarks under the regular provisions of the Lanham Act, it is significant to keep this distinction in mind. The FTDA is a departure from 200-plus years of common law trademark protection in the United States. ${ }^{39}$ The confusion over the FTDA is only heightened by the fact that the Lanham Act is an act that codifies the common law, it does not grant new rights. ${ }^{40}$ If the Lanham Act granted new rights, the argument went in 1947 when it was adopted, it would be unconstitutional. ${ }^{41}$ It is hard to imagine the FTDA as anything other than granting new rights and the source of these new rights is the fact that the FTDA grants rights in gross when no trademark prior to the FTDA was recognized in gross.

Under traditional trademark jurisprudence, the trademark right in the United States has no existence independent from the "goodwill appurtenant thereto" its use on or in connection with some good or service. ${ }^{42}$ This means that the holder of a trademark must be able to specifically name the goods or services on which or with which the mark is used. Failing that, there are no trademark rights.

The FTDA changes this calculus. Under the FTDA, this close connection to the specific goods or services on which the mark is used is minimized and, perhaps, even extinguished. Once free of the goodwill that the mark has come to symbolize, trademark holders are able to treat the mark as a commodity and buy, sell, and hypothecate the mark freely. As we shall see below, ${ }^{43}$ this is why non-famous, non-iconic marks not technically eligible for the FTDA struggle to make arguments in litigation that they are famous when they, in fact, are not.

15 U.S.C. $\$ 1125(c)(1)$ (2012) (emphasis added). The italicized portion demonstrates that the dilution right is one in gross with no connection to the goodwill or commerce represented by the mark.

38. See, e.g., Mead Data Cent., Inc. v. Toyota Motor Sales, U.S.A., Inc., 875 F.2d 1026, 1039-40 (2d Cir. 1989) (finding that "Lexus" does not dilute "Lexis").

39. George Washington was the holder of the first trademark in what became the United States. Beverly W. Pattishall, Two Hundred Years of American Trademark Law, 68 TRADLMARK REP. 121, 121-22 (1978). His mark was "G. Washington" brand tlour. Id.

40. Kenneth L. Port, The "Unnatural" Expansion of Trademark Rights: Is a Federal Dilution Statute Necessary?, 18 SETON HALl LEGIS. J. 433, 460 (1994).

41. 92 CONG. REC. 7524 (1946); Port, supra note 40, at 460

42. Rogiz M. Milgrim \& ERIC E. BENSEN, 2 Milgrim ON LiCENSLiv 15-55 (2017) (footnote omitted).

43. See infra Part III 


\section{DILUTION LITERATURE}

The record is replete with consistent literature critical of the FTDA. ${ }^{44}$ There is a plethora of well-placed and well-reasoned articles that criticize the FTDA. ${ }^{45}$ It is extremely difficult to find any that support the FTDA. It is safe to say that authors of this literature (mostly academics) today do not support the FTDA.

The supporters of the FTDA were and remain practicing attorneys and their surrogate, the International Trademark Association ("INTA"). ${ }^{46}$ For all the positives that INTA has provided in supporting and encouraging knowledge and information about brands and brand management, its irrational support of trademark dilution in light of all of this contrary literature is peculiar. As INTA remains an organization formed by, for and with trademark holders in mind, it is not surprising that they would support a cause of action that seems to expand the scope of their domain. However, with all of this contrary literature, one wonders to whom they are listening. Further, the FTDA has, in the end, done more harm than good for the cause of recognizing and protecting legitimate trademark rights.

I mean no specific criticism of INTA as it has done my and other academics' careers great favors. I merely point out an interesting disconnect. That is, generally speaking, authors of literature on the FTDA are opposed to the FTDA and trademark holders support it. That is, there is a great divide in trademark jurisprudence in the United States

44. "Literature" here is defined as law review articles.

45. See, e.g. Paul J. Heald \& Robert Brauneis, The Myth of Buick Aspirin: An Empirical Studh of Trademark Dilution by Product and Trade Names, 32 CARDozo L. Rev. 2533, 2533. 2546 (2011) (arguing that "brand sharing"--the act of using someone else's famous mark as corporate names or trade names-is common in the United States but are almost never used as trademarks on products; and stating that "psychological studies help explain why the harm allegedly caused by unauthorized sharing (denominated 'dilution' by Congress) is unlikely ever to occur"); see also Laura R. Bradford, Emotion. Dilution, and the Trademark Consumer, 23 BERKELEY TECH. L.J. 1227, 1254 (2008): Mark A. Lemley, The Modern Lanham Act and the Death of Common Sense, 108 YALE L.J. 1687. 1698-99 (1999); Long, supra note 18, at 1033-37; Gary Myers, Statutory Interpretation, Property Rights, and Boundaries: The Nature and Limits of Protection in Trademark Dihution. Trade Dress, and Product Configuration Cases, 23 COLUM.-VLA J.L. \& ARTS 241, 27881 (2000); Sara Stadler Nelson, The Wages of Ubiquity in Trademark Law, 88 IOWA L. REV. 731, 732 (2003) ("Courts and scholars have spilled a great deal of ink on the subject of trademark dilution...."); Sandra L. Rierson, The Myth and Reality of Dilution, 11 DUkE L. \& TECH. REV. 212, 234-48 (2012); David S. Welkowitz, The Supreme Court and Trademark Law in the New Millennium, 30 WM. Mitchell L. REV. 1659, $1681-85$ (2004).

46. INTA (formerly known as the United States Trademark Association ("USTA")) puts much weight behind the claim that dilution started with a law review article by Frank Schechter. Frank Schechter, The United States Trademark Association Trademark Review Commission Report and Recommendations to USTA President and Board of Directors, 77 TRADEMARK REP. 375, 45457.454 n. 132 (1987) (citing Schechter, supra note 14). 
today. Commentators do not support the FTDA while INTA (representing trademark holders) remains steadfastly married to it. ${ }^{47}$

The criticisms of the FTDA are not on the margins or remote. The attacks are central to the organization of the United States' judicial system and central to the Lanham Act. These attacks have been wellreasoned and vigorously argued. Yet, they fall on the deaf ears of INTA, the practicing bar, and, most importantly, Congress.

I have written several articles pointing out the conceptual problems with trademark dilution. ${ }^{48}$ If I were alone, it might be understandable why I was ignored; however, I am far from alone. In fact, an entire subgroup or cottage-industry among academics has developed since 1996 which focuses on pointing out the jurisprudential flaws of trademark dilution.

Since 1996, there have been hundreds of articles written about trademark dilution. Most of the articles are quite critical of the FTDA and/or the Trademark Dilution Revision Act of 2006 ("TDRA"). ${ }^{49}$ Many articles focus on the likelihood versus the actual harm test addressed in Moseley v. $V$ Secret Catalogue, Inc. ${ }^{50}$ and the resulting amendment to the FTDA. ${ }^{51}$ Other popular topics include the effect the FTDA has on parody, ${ }^{52}$ the inconsistency between the Second and Fourth Circuits in

47. See, e.g., Mark A. Finkelstein \& Michelle Stover, Trademurk Dilution. Recent U.S. Case Law Rejects Requirement that Marks Must Be "Identical" or "Substantially Similar", INTA BuLL., Sept. 1, 2012, http:/www.inta.org/INTABulletin/Pages/TrademarkDilutionRecentUSCase LawRejectsRequirementThatMarksMustBe $\% \mathrm{E} 2 \% 80 \% 9 \mathrm{C}$ Identical $\% \mathrm{E} 2 \% 80 \% 9 \mathrm{Dor} \% \mathrm{E} 2 \% 80 \% 9 \mathrm{C}$ SubstantiallySimilar\%E2\%80\%9D.aspx (describing some INTA efforts at shaping dilution cases).

48. Kenneth L. Port, Judging Dilution in the United States and Japan, 17 TRANSNAT'L L. \& CONTEMP. Probs. 667, 668-85 (2008); Kenneth L. Port, The Expansion Trajectory: Trademark Jurisprudence in the Modern Age, $92 \mathrm{~J}$. PAT. COPYRIGHT \& TRADEMARK OFF. SOC'Y 474. 482-83 (2010) (arguing that trademark dilution is one aspect of the inextricable expansion of trademark jurisprudence in the United States and inconsistent with the legislative history of the Lanham Act, the Act itself, and the Constitution); Port, supra note 26, at 602-07 (arguing that the FTDA gives trademark holders the perverse incentive to engage in trademark bullying). See generally Port, supra note 6 (arguing that as trademark jurisprudence in the United States expands via concepts incorporated into the FTDA, the United States approaches a civil law view of the trademark right which perceives the mark itself as property); Port, supra note 40, reprinted in Kenneth L. Port, The

"Unnatural" Expansion of Trademark Rights: Is a Federal Dilution Statute Necessan??, 85 TRADEMARK REP. 525 (1995) (arguing that a federal statute to proscribe trademark dilution is unnecessary as there is no cognizable harm in the dilution of famous marks).

49. Pub. L. 109-312, 120 Stat. 1730 (2006) (codified in 15 U.S.C. $\$ \$ 1052,1063,1064,1092$, $1125,1127(2006))$.

50. Moseley v. V Secret Catalogue, Inc., 537 U.S. 418, 432-34 (2003), superseded by statute. 120 Stat. 1730, aff'd, 605 F.3d 382 (6th Cir. 2003).

51. See, e.g., Monica Hof Wallace, Using the Past to Predict the Future: Refocusing the Analysis of a Federal Dilution Claim, 73 U. CIN. L. REv. 945, 974 (2005).

52. Eugene C. Lim, Of Chew Toys and Designer Handbags: A Critical Analysis of the "Parody" Exception Under the U.S. Trademark Dilution Revision Act, 35 CAMPBELL L. REV. 83. 90-99 (2012); Keren Levy, Note, Trademark Parody: A Conflict Between Constitutional and 
their substantive application of the appropriate test for trademark dilution, ${ }^{53}$ and what constitutes a "famous mark" under the FTDA. ${ }^{54}$ One article even persuasively argued that dilution doctrine is not consistent with the First Amendment. ${ }^{55}$

I am not naïve enough to believe that any practicing attorney would read or specifically rely on any law review article. For a long time in the United States, there has been a belief that legal literature has nothing to teach the practicing bar and, therefore, it largely goes discounted if not entirely ignored. However, rarely is the disconnect as large as it is with trademark dilution literature. With commentators telling INTA and the practicing bar that not only are they on the wrong side of history, but, also, on the wrong side of a rational and reasonable development of the very law they practice, it is peculiar that it goes ignored and ignored vociferously (if that is possible).

INTA not only ignores the academic critiques of dilution, but also actively and aggressively supports its adoption in other countries other than the United States. ${ }^{56}$

Most importantly, Congress also ignores this literature. ${ }^{57}$ As there are few academics or other authors of the literature who can afford to lobby Congress, it is easy to see how and why it is dismissed. This Article is a call to Congress to take this literature into account when contemplating trademark dilution and, hopefully, repealing it.

Intellectnal Property Interests, 69 GEO. WASH. L. REV. 425, $435-47$ (2001); Anthony Pearson, Note, Commercial Trademark Parody, the Federal Trademark Dilution Act, and the First Amendment, 32 VAl. U. L. REV. 973, 1005-22 (1998); Julie Zando-Dennis, Note, Not Plaving Around: The Chilling Power of the Federal Trademark Dilution Act of 1995, 11 CARDozo WOMLN's L.J. 599, 6I6-19 (2005).

53. Anna K. Wong, Big Business in Their Belfry? Congress to Dumb Down Dilution, 6 LoY. L. \& TECH. ANN. 43, $52-57$ (2006) (discussing the circuit split between the Fourth Circuit in Ringling Bros.-Barmum \& Bailey Combined Shows, Inc. 1: Utah Division of Travel Development and the Second Circuit in Nabisco, Inc. v. PF Brands, Inc. (first citing Ringling Bros.-Barnum \& Bailey Combined Shows, Inc. v. Utah Div. of Travel Dev., 170 F.3d 449 (4th Cir. 1999) (holding that actual dilution was required), overruled in part bv Moselev, 537 U.S. 418 ; and then citing Nabisco. Inc. v. PF Brands, Inc., 191 F.3d 208 (2d Cir 1999) (holding that likelihood of dilution was the test of dilution))).

54. Xuan-Thao Nguyen, Fame Law: Requiring Proof of National Fame in Trademark Law, 33 CARDOZO L. REV. 89, 99-122 (2011).

55. See Rebecca Tushnet, Gone in Sixty Milliseconds: Trademark Law and Cognitive Science, 86 TEX. L. REV. 507, 554-58 (2008).

56. Trevor Little, INTA President Expects 'Evolution Not Revolution' as the Association Looks to Embrace the Wider Brand Community, World TRADEMARK REV. (Feb. 6, 2017), http://www.worldtrademarkreview.com/blog/detail.aspx?g=348e $0 \mathrm{e} 05-3 \mathrm{a} 3 \mathrm{e}-40 \mathrm{cc}-8 \mathrm{a} 18$ $42 \mathrm{~d} 337703463$.

57. Jane Ann Levich, Ambiguity in Federal Dilution Law Continues: Levi Strauss \& Co. v. Abercrombie \& Fitch Trading Co., Case in Point, 27 BERKELEY TECH. L.J. 677, 691-92 (2012). 
If Congress were to read and think about some of this literature, it would surely give it pause. The literature is direct and openly hostile to the FTDA. One of the earliest articles warned that dilution protection poses "an anticompetitive threat to market efficiency and consumer welfare. $"{ }^{58}$ A student comment prophetically predicted that:

One of the primary motivations for enactment of a federal dilution law was to provide a single, nationwide solution to the problems of patchwork protection against the gradual erosion of a mark's distinctiveness. Because dilution is difficult to pin down and impossible to measure, the FTDA necessarily suffers from some vagueness. This in turn makes a uniform, nationwide solution unlikely, at least until a significant FTDA case reaches the Supreme Court. ${ }^{59}$

Of course, that Supreme Court case did arise in Moseley, but Congress overruled that case with the TDRA. ${ }^{60}$ At any rate, a uniform, national standard still eludes us as the appellate courts still apply the FTDA disparately. ${ }^{61}$

Perhaps the most prophetic article was written in 1991, well before the adoption of the FTDA. It claimed that trademark dilution provided an overly broad scheme that would be counterproductive in the end. ${ }^{62}$

Again, a student note sums up the fight against the FTDA rather succinctly as follows:

Dilution protection is a largely unnecessary and costly safeguard that can undermine the objectives of trademark law by producing anticompetitive results. A likelihood of dilution determination is conceptually difficult to apply and as a result courts rely on it unnecessarily. In addition, the injury is speculative and difficult to measure. ${ }^{63}$

Rebecca Tushnet makes a central attack on the constitutional legitimacy of trademark dilution as follows:

Though the cognitive theory of dilution is internally consistent and appeals to the authority of science, it does not rest on sufficient empirical evidence to justify its adoption. Moreover, the harms it identifies do not generally come from commercial competitors but

58. Klieger, supra note 2, at 795 .

59. Lori Krafte-Jacobs, Comment, Judicial Interpretation of the Federal Trademark Dilution Act of 1995, 66 U. CIN. L. REV. 659, 696 (1998).

60. Wong, supra note 53 , at 64-66.

61. Levich, supra note 57, at 692; Wong, supra note 53, 52-57.

62. David S. Welkowitz, Reexamining Trademark Dilution, 44 VAND. L. REV. 531, 538-46 (1991).

63. William Marroletti, Note, Dilution, Confusion, or Delusion? The Need for a Clear Iniernational Standard to Determine Trademark Dilution, 25 BRoOK. J. INT'L L. 659, 692 (1999). 
from free speech about trademarked products. As a result, even a limited dilution law should be held unconstitutional under current First Amendment commercial-speech doctrine. In the absence of constitutional invalidation, the cognitive explanation of dilution is likely to change the law for the worse. Rather than working like fingerprint evidence - which ideally produces more evidence about already-defined crimes - psychological explanations of dilution are more like economic theories in antitrust, which changed the definition of actionable restraints of trade. Given the empirical and normative flaws in the cognitive theory, using it to fill dilution's theoretical vacuum would be a mistake. ${ }^{64}$

There is not even common ground on who is the appropriate fact finder in a dilution case, a judge or a jury. ${ }^{65}$ Some see the judiciary being resistant to application of dilution principles because it grossly expands trademark rights based on non-traditional trademark rationales. ${ }^{66}$ Some have even challenged whether dilution provides a remedy where there is no injury. ${ }^{67}$ Some have expanded the criticism of the TDRA for inappropriately extending dilution protection to descriptive marks and broadening its application to trade dress all in a manner that is inconsistent with prevailing case law which takes a more restrictive approach. ${ }^{68}$ Some have empirically pointed out that borrowing of truly famous trademarks (the presumed harm in dilution) very rarely actually happens. ${ }^{69}$ Or that the requisite showing of fame is obtuse at best. ${ }^{70}$ Or even worry about whether dilution protection will lead to an apoplectic world where everything, the moon, the sun, etc., are owned and in which exclusive rights are claimed. ${ }^{71}$

64. Tushnet, supra note 55, at 507.

65. See David S. Welkowitz, Who Should Decide? Judges and Juries in Trademark Dihution Actions, 63 MERCER L. REV. 429, 452-64 (2012)

66. See, e.g., Joshua G. Jones, The "Inequities" of Dilution: How the Judician May Use Principles of Equity to Frustrate the Intent of the Federal Trademark Dilution Act. 91 J. PAT. \& TRADEMARK OFF. SOC'Y 200,217 (2009) ("The judiciary at both the state and federal levels have been extremely resistant to dilution because it radically expands the scope of trademark holder's rights. Not only does dilution expand these rights but it does so based on none of the traditional trademark rationales.").

67. See, e.g., Karen Jacobs Louden \& Tiffany Fonseca, Does the Federal Trademark Dilution Act Provide a Right Without a Remedr? The Supreme Court's First Forav into Trademark Dilution: Moseley v. V Secret Catalogue, 7 DEL. L. REv. 31, 33 (2004).

68. See, e.g. Robert G. Bone, A Skeptical View of the Trademark Dilution Revision Act, 11 INTELL. PROP. L. BULL. 187, 195-98 (2007)

69. See, e.g., Heald \& Brauneis, supra note 45, at 2562.

70. See, e.g., Adam Omar Shanti, Comment, Measuring Fame: The Use of Empirical Evidence in Dilution Actions, 5 MARQ. INTELL. PROP. L. REV. 177, 185-89 (2001).

71. See, e.g., Natalic J. McNeal, Note, Trademark: Victoria's Dirty Little Secret: A Revealing Look at What the Federal Trademark Dilution Act Is Tning to Conceal, 56 OKLA. L. REV. 977 , 1000-02 (2003). 
Perhaps the best defense of trademark dilution appeared in a 2004 article. ${ }^{72}$ This article argued that the claims that trademark dilution are somehow mystical and incomprehensible are largely misplaced. Rather than focusing on defining the verb used (likelihood or actual) to modify the noun (dilution), we should focus on the fact that a qualitative weighing (comparing trademarks) has always occurred in trademark infringement jurisprudence. The test of likelihood of dilution or actual dilution is less relevant than the idea that this qualitative weighing take place. Does the junior mark interfere somehow with the senior mark? If so, the author argues, "[d]ilution should no longer be seen as a mystical construct, but instead should take its rightful place alongside the traditional confusion-based theory with which it shares more in common than has heretofore been acknowledged." 73

Professor Barton Beebe also provides a defense of the TDRA by claiming it is "a sensible and progressive reform of American federal antidilution protection." ${ }^{14}$ Professor Beebe, being one of a very few number of academic commentators who have written positively about dilution, nevertheless is very careful of his support. He urges courts to avoid impenetrable words like "dilution" and focus, instead, on two, distinct causes of action provided for in the TDRA: anti-tarnishment protection and anti-blurring protection. ${ }^{75}$ Perceived this way, Professor Beebe argues, it provides a sustainable model of meaningful protection for trademark holders. ${ }^{76}$ However, Beebe is also cognizant of the fact that the existence of the FTDA gives actors incentives "to find in the term 'dilution' a receptacle for all imaginable harms to their marks." 77

Additionally, others claim to be able to show statistically that dilution is a real thing. ${ }^{78}$

However, it is clear that the vast majority of the hundreds of articles produced regarding the controversial topic of trademark dilution have viewed it negatively. These articles are all published and readily

72. See generally, Thomas R. Lee, Demystifying Dilution, 84 B.U. L. REV. 859 (2004)

73. Id. at 944.

74. Barton Beebe, A Defense of the New Federal Trademark Antidilution Law, 16 FORDHAM INTELL. PROP. MEDIA \& ENT. L.J. 1143,1144 (2006).

75. Id. at $1156-74$.

76. $I d$.

77. Id. at 1174

78. See, e.g., Sungho Cho, Empirical Substantiation of Sport Trademark Dilution: QuasiExperimental Examination of Dilutive Effects, 25 J. LEGAL ASPECTS SPORT 27, 40-47 (2015); Julie Manning Magid et al., Quantifying Brand Image: Empirical Evidence of Trademark Dilution, 43 AM. BUS. L.J. 1, 4, 26-38 (2006) ("[O]utlin[ing] a randomized experiment for proving actual dilution [and] conclud[ing] that the Court's legitimizing consumers' brand image through trademark dilution law is an important advancement in trademark protection."). 
available. However, the practicing bar manifested by INTA remains steadfastly supportive of the dilution cause of action.

\section{CONGRESS'S UNWAVERING SUPPORT FOR THE FTDA}

Congressional support of the FTDA has also been replete if not vociferous. The narrative created around dilution when it was being originally drafted and then amended was that there was a major economic harm that was going unaddressed that, if not addressed, would have major consequences for American corporations, even though those consequences were never spelled out in any way relying on verifiable data. $^{79}$ When the FTDA was being introduced, the House Report attached to the Bill stated, in part:

Moreover, the recently concluded Agreement on Trade-Related Aspects of Intellectual Property Rights, including Trade in Counterfeit Goods ("TRIPS") which was part of the Uruguay Round of the GATT agreement includes a provision designed to provide dilution protection to famous marks. Thus, enactment of this bill will be consistent with the terms of the agreement, as well as the Paris Convention, of which the U.S. also a member. ${ }^{80}$

That is, the House Report contemplates that the FTDA is "consistent" with TRIPS.

The Senate apparently felt the same way:

Moreover, Mr. President, the GATT agreement includes a provision designed to provide dilution protection to famous marks. Thus, enactment of this bill will be consistent with the terms of the agreement, as well as the Paris Convention, of which the United States is also a member. Passage of a Federal dilution statute, Mr. President, would also assist the executive branch in its bilateral and multilateral negotiations with other countries to secure greater protection for the famous marks owned by U.S. companies. Foreign countries are reluctant to change their laws to protect famous U.S. marks if the United States does not afford special protection for such marks. ${ }^{81}$

As a further statement from Senator Leahy makes clear, the United States considered dilution protection to be a bargaining chip with our trading partners:

79. H.R. REP. No. 104-374, at 3-4 (1995)

80. Id. at 4. GATT refers to the General Agreement on Tariffs and Trade, Oct. 30, 1947, 61 Stat. A-11, 55 U.N.T.S. 194.

81. 141 CONG. REC. 38,559 (1995) (statement of Sen. Orrin Hatch). 
Mr. President, passage of this bill is part of our effort to improve intellectual property protection around the world. I hope that it will serve to improve trademark enforcement domestically and serve as a model for our trading partners overseas. ...

We intend for this legislation to strengthen the hand of our international negotiators from the Office of the U.S. Trade Representative and the Department of Commerce as they press for bilateral and multilateral agreements to secure greater protection for the world famous marks of our U.S. companies. Foreign countries should no longer argue that we do not protect our marks from dilution, nor seek to excuse their own inaction against practices that are destructive of the distinctiveness of U.S. marks within their borders. ${ }^{82}$

With remarkably imprecise language, INTA also supported the FTDA as if it were an "international norm" as follows:

The enactment of a proposed federal dilution statute would also harmonize U.S. trademark law with that of other nations and assist our country's trade negotiators in persuading other countries to protect famous trademarks owned by U.S. companies. ... Other countries, including some of our major trading partners, recognize the wisdom of dilution statutes. Canada has protected famous marks from dilution since 1953. More recently, Japan, Spain, Greece, and Venezuela have adopted dilution laws. ${ }^{83}$

From this representation, one would think that the United States was grossly trailing other countries' enlightened adoption of dilution protection in 1996. In 1993, Japan did adopt a statutory revision that has come to be identified as providing for dilution-like protection, but, in 1996, there were, as of yet, no Japanese cases that applied this statutory revision in this manner. In addition, the Japanese term for "dilution" (“希釈") appears in no statute, including in the so-called dilution statute. In fact, the Japanese statute merely states as follows: "[T] he act of using Goods or Other Appellations of another that are identical with, or similar to, another person's famous Goods or Other Appellations" an infringement.

82. Id. at 38,561 (statement of Sen. Patrick Leahy).

83. Madrid Protocol Implementation Act and Federal Trademark Dilution Act of 1995 . Hearing Before the Subcomm. on Court and Intellectual Prop. of the Judiciany H.R., 104th Cong. 82 (1995) (statement of Mary Ann Alford, Vice President \& Assistant Gen. Counsel, Intellectual Prop., Rebook Int'l Ltd., \& Exec. Vice President, Int'I Trademark Ass'n).

84. Kenneth L. Port, Trademark Dilution in Japan, 4 Nw. J. TECH. \& INTELL. Prop. 228, 229 (2006) (translating Fuseikyoso Boshiho [Unfair Competition Prevention Act], Law No. 47 of 1993, art. 2-1-2 (Japan)). 
It is easy today to see this provision as dilution-like protection, but, in 1996, there was no real indication that it would or should be interpreted as such. In fact, as a provision of the Unfair Competition Prevention Act ("UCPA"), it could easily be applied to far broader acts of unfair competition other than trademark dilution. ${ }^{85}$ Most importantly, the Japanese statute is silent on competition. Dilution is said to apply to situations where there is no competition between the parties. ${ }^{86}$ That is, dilution protection is granted specifically when there is no competition regardless of confusion. As the Japanese statute provides no express language on the role of competition, it is a stretch to call this dilutionlike protection as this appears in the UCPA.

The Canadian statute has provided dilution-like protection since 1953; however, until 2006 this provision went largely ignored by the Canadian courts. ${ }^{87}$ In Veuve Clicquot Ponsardin v. Boutiques Cliquot, Ltéed. ${ }^{88}$ the court did grant an injunction as it found that the defendant's conduct "is likely to have the effect of depreciating the value of the goodwill." 89 This case arose in 2006. In 1996, it would be rather disingenuous to represent to Congress that Canada had a dilution-like statute when it had never been applied in any specific case.

Of course, as Spain and Greece are part of the European Union, their national laws on trademarks become somewhat confused. However, the statement in 1995 that Spain protected trademarks from dilution is simply incorrect. The first Spanish trademark law that protected famous marks from dilution occurred in $2001 .{ }^{90}$ Greek trademark dilution commenced in $1994 .^{91}$

Therefore, INTA's testimony to Congress in 1995 that Japan, Canada, Spain, and Greece had enacted trademark dilution laws, implying that the United States was delayed in adopting such a statute

85. See, e.g., [Osaka Dist. Court,] Jan. 21, 2014 (finding that suit is proper under Article 2-1-2 of the UCPA but that the "DeNA BAYSTARS" (in English) (a professional baseball team) does not infringe on the DNA Corporation's trademark (DNA in Japanese)).

86. Port, supra note 84, at 233-34.

87. See Mark D. Janis \& Peter K. Yu, International and Comparative Aspects of Trademark Dilution, 17 TRANSNAT'L L. \& CONTEMP. PROBS. 603, 606-07 (2008).

88. (2006), I S.C.R. 824 (Can.).

89. Trade-Marks Act, R.S.C. 1985, c T-13, \& 22(1) (Can.).

90. Trademarks Law (R.C.L. 2001, 17) (Spain).

91. Greece Act Number 2239/1994 adopted a version of the European Union directive on trademarks. Compare (1994: 2239) [Trademark Law], (Greece), with Council Directive 89/104, 1989 O.J. (L 040) (EC). Article 4 of the Act allows owners of famous marks to block the registration of similar marks on non-similar goods. See Nicolas K. Dontas, Greece, in INTELLECTUAL PROPERTY LAW IN THE EUROPEAN COMMUNITY: A COUNTRY-BY-COUNTRY REVIEW 190-91 (Angus Phang et al. eds., 2004). It does not provide a positive right upon which one might sue and enjoin non-competing use. Therefore, to claim that it is in anyway similar to United States dilution law is misleading at best. 
and was under some international pressure to comply, rather than far out front, was either a fabrication, a misrepresentation or simply disingenuousness. At any rate, this testimony that seems to have been instrumental in getting Congress to pass the FTDA was inaccurate. More accurate would have been to say that the United States was the leader in the effort to get other nations to adopt a dilution statute. More accurate yet would be to say that INTA believed that protecting American famous marks from a theoretical harm by granting broad trademark rights beyond what any country had theretofore recognized was somehow the normative goal.

As will be explicated below, this theoretical harm, also known as dilution, either never actually occurs ${ }^{92}$ or occurs so infrequently that there are nearly no reported cases in the United States. That is, the actual world leader in this cause of action has led other countries into an abyss where trademark rights are unlimited, where competition is irrelevant, and where the objective is to commodify and hypothecate the trademark. ${ }^{33}$ These goals are inconsistent with the objective of trademark protection-to prevent one manufacturer from representing itself as the source of a good or service when it is not. ${ }^{94}$

The TRIPS Agreement was signed and ratified in $1994 .^{95}$ The TRIPS Agreement has become the most important international agreement on the international harmonization of intellectual property laws around the world. "Whether the FTDA was "consistent" with the

92. Heald \& Brauneis, supra note 45 , at 2533 ("We conclude by examining the stillwidespread phenomenon of brand sharing and find that recent psychological studies help explain why the harm allegedly caused by unauthorized sharing (denominated 'dilution' by Congress) is unlikely ever to occur.").

93. See infra Part VI.

94. Learned Hand referred to this as the "Law of the Prophets," that "one merchant shall not divert customers from another by representing what he sells as emanating from the second." Yale Elec. Corp. v. Robertson, 26 F.2d 972, 973 (2d Cir. 1928); see also Kenneth L. Port, Learned Hand's Trademark Jurisprudence: Legal Positivism and the Myth of the Prophet, 27 PAC. L.J. 221, 232-33 (1996) (quoting Yale Elec. Corp., 26 F.2d at 973).

95. Agreement on Trade-Related Aspect of Intellectual Property Rights, Apr. 15, 1994, Marrakesh Agreement Establishing the World Trade Organization, Annex 1C, 1869 U.N.T.S. 299 [hereinafter TRIPS Agreement].

96. See Daniel J. Gervais, The TRIPS Agreement and the Doha Round: History and Impact on Economic Development, in 4 INTELLECTUAL Property and INFORMATION WEALTH: ISSUES AND Practices in the Digital Age 23, 43 (Peter K. Yu ed., 2007); J.H. Reichman \& David Lange, Bargaining Around the TRIPS Agreement: The Case for Ongoing Public-Private Initiatives to Facilitate Worldwide Intellectual Property Transactions, 9 DUKE J. COMP. \& INT'L L. 11 passim (1998); J.H. Reichman. The TRIPS Agreement Comes of Age: Conflict or Cooperation with the Developing Countries? 32 CASE W. RES. J. INT'L L. 441, 444-56 (2000); Peter K. Yu, From Pirates to Partners (Episode II): Protecting Intellectual Property in Post-WTO China, 55 AM. U. L. REV. 901, 941 fig.2 (2006); Peter K. Yu, TRIPS and Its Discontents, 10 MARQ. INTELL. Prop. L. ReV. 369. 402 (2006) ("[T]he international intellectual property regime, to some extent, is handicapped 
United States' obligations under the TRIPS Agreement deserves some thought and analysis as the above representations were made that the FTDA was consistent with the United States' obligations under the TRIPS Agreement.

In fact, it is not consistent with TRIPS and it is an odd bargaining chip. The relevant portion of the TRIPS Agreement reads as follows:

Article 6bis [related to the protection of famous marks] of the Paris Convention (1967) shall apply, mutatis mutandis, to goods or services which are not similar to those in respect of which a trademark is registered, provided that use of that trademark in relation to those goods or services would indicate a connection between those goods or services and the owner of the registered trademark and provided that the interests of the owner of the registered trademark are likely to be damaged by such use. ${ }^{97}$

The emphasized language "indicate a connection between" in Article 16-3 quoted above ${ }^{98}$ is inconsistent with both the FTDA and courts' application of the doctrine. In this regard, the FTDA states:

\begin{abstract}
Subject to the principles of equity, the owner of a famous mark that is distinctive, inherently or through acquired distinctiveness, shall be entitled to an injunction against another person who, at any time after the owner's mark has become famous, commences use of a mark or trade name in commerce that is likely to cause dilution by blurring or dilution by tarnishment of the famous mark, regardless of the presence or absence of actual or likely confusion, of competition, or of actual economic injury. ${ }^{99}$
\end{abstract}

Here, the emphasized portion claims that this cause of action attaches "regardless" of the "connection" Article 16-3 of the TRIPS requires. That is, the two are very inconsistent. The Lanham Act dilution cause of action is much broader than that contemplated under TRIPS. Under TRIPS, a "connection" must be shown; under the Lanham Act, the cause of action attaches "regardless" of any connection. Another word for the "connection" contemplated by the TRIPS Agreement would, of course, be "confusion as to source," precisely what the FTDA expressly excludes.

In addition, after the Supreme Court held in Moseley v. V Secret Catalogue, Inc. that the correct standard for determining when dilution

\footnotetext{
by its lack of maximum standards.").

97. TRIPS Agreement, supra note 95, art. 16-3 (last emphasis added)

98. See supra note 97 and accompanying text

99. 15 U.S.C. $\$ \$ 43(c)(1), 1125(c)(1)(2012)$ (emphasis added).
} 
occurs is "actual dilution," 100 Congress in 2006 specifically overruled the Supreme Court in the TDRA and made the standard the lower "likelihood of dilution" test. ${ }^{101}$ The trademark lobby is the only winner in this scenario.

Following Moseley, most academic commentators concluded that the Supreme Court got it right. By looking at the poorly drafted FTDA, the Court found an obvious inconsistency. In one place, the Lanham Act referenced "causes dilution"102 and in another place the Lanham Act defines dilution as "the lessening of the capacity" 03 of a famous mark to identify and distinguish goods and serves thereby marked.

In March of 2003, in Moseley, the United States Supreme Court drew a new line in the sand regarding the FTDA and attempted to finally curtail the heretofore resplendent Congressional expansion of the law of trademark dilution. Justice Stevens's opinion had the result of making trademark dilution causes of action much less attractive.

Victoria's Secret had registered its principal mark on January 20, 1981 , for use on lingerie and other women's apparel. ${ }^{104}$ By the time the litigation commenced, Victoria's Secret had 750 stores nationwide, distributed 400 million catalogues, and had sent more than 39,000 copies of its catalogues to Elizabethtown, Kentucky, where the defendant was located. ${ }^{105}$ In 1998 alone, Victoria's Secret had spent $\$ 55$ million in advertising and its gross sales exceeded $\$ 1.5$ billion. ${ }^{106}$

FIGURE 1:

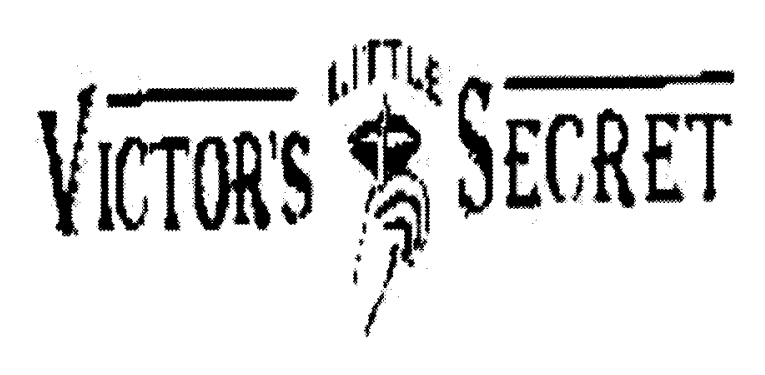

100. Moseley v. V Secret Catalogue, Inc., 537 U.S. $418,432-34$ (2003), superseded by statute, Trademark Dilution Revision Act of 2006, Pub. L. No. 109-312, 120 Stat. 1730 (codified as amended in 15 U.S.C. $\S \S 1052,1063,1064,1092,1125,1127$ (2006)), aff'd, 605 F.3d 382 (6th Cir. 2010).

101. Trademark Dilution Revision Act, sec. $2, \S 43,120$ Stat. 1730, 1730-32.

102. 15 U.S.C. $\$ 1125$ (c)(1) (2000, amended 2012).

103. 15 U.S.C. $\$ 1127$ (2000, repealed 2006).

104. V Secret Catalogue, Inc. v. Moseley, 259 F.3d 464, 466 (6th Cir. 2001), rev'd, 537 U.S. 418.

105. Moseley, 259 F.3d at 466

106. Moseley, 537 U.S. at $422-23$. 
That is, there was no question that Victoria's Secret's trademark was famous.

In 1998, Victor and Cathy Moseley opened a retail store advertising and selling adult novelty items including lingerie and adult erotica. They referred to their establishment as "Victor's Secret."107 After an army colonel based at nearby Fort Knox sent Victoria's Secret a copy of an advertisement showing the Moseleys's usage, Victoria's Secret immediately demanded the Moseley's cease and desist from further infringing or diluting Victoria's Secret's trademark. ${ }^{108}$ When the Moseleys simply changed the mark to read "Victor's Little Secret," Victoria's Secret filed suit claiming, among other things, trademark infringement and dilution. ${ }^{109}$ The Moseleys's final mark appeared as above. ${ }^{110}$

Victoria's Secret's trademark infringement claim was dismissed by summary judgment at trial and Victoria's Secret did not appeal this issue. ${ }^{111}$ However, noting the tarnishing effect that the Moseleys's use would have on the Victoria's Secret mark, the court held in favor of Victoria's Secret on their dilution claim and issued an injunction against the Moseleys, and the Sixth Circuit affirmed. ${ }^{1 / 2}$

The question on appeal to the Supreme Court was whether or not a plaintiff claiming dilution had to show objective evidence of actual dilution or whether the standard for dilution was a "likelihood of dilution."113 There had been a split in the Circuits on this specific issue. The Fourth, ${ }^{114}$ Fifth, ${ }^{15}$ and Seventh ${ }^{116}$ Circuits required actual dilution, while the Second ${ }^{17}$ and Sixth $^{118}$ Circuits had held that a likelihood of

107. Id. at 423 .

108. $I d$.

109. Id. at 423-24

110. See supra fig.1.

111. See V Secret Catalogue, Inc. v. Moseley, 259 F.3d 464, 467 (6th Cir. 2001), rev'd. 537 U.S. 418. Of course, the last thing Victoria's Secret would want is to claim that the Moseleys were in competition with Victoria's Secret, the requisite claim to a trademark infringement action. That is, to claim there was competition with the Moseleys, Victoria's Secret would have to claim that the hardcore porn store competed with its softcore image. As such, they had no interest in appealing the infringement claim. However, Victoria's Secret has subsequently started a line of products it has labeled "Victoria's Little Secrets" for fragrances.

112. Moselev, 259 F.3d. at 467-68, 471-77.

113. Moselev, 537 U.S. at 421-22.

114. See Ringling Bros.-Barnum \& Bailey Combined Shows, Inc. v. Utah Div. of Travel Dev., 170 F.3d 449, 464 (4th Cir. 1999).

115. See Scott Fetzer Co. v. House of Vacuums Inc., 381 F.3d 477, 489 n.9 (5th Cir. 2004).

116. See Sullivan v. CBS Corp., 385 F.3d 772, 779 (7th Cir. 2004).

117. See Nabisco. Inc. v. PF Brands, Inc., 191 F.3d 208, 228-29 (2d Cir. 1999).

118. See Kellogg Co. v. Exxon Corp., 209 F.3d 562, 568 (6th Cir. 2000), summary judgment granted in part, summary judgment denied in part, 92 F. Supp. 2d 790 (W.D. Tenn. 2001), overnuled in part by Moseley v. V Secret Catalogue, 537 U.S. 418 (2003), superseded by statute, 
dilution was sufficient. The Supreme Court granted certiorari with the express purpose of resolving this split. ${ }^{119}$

The Supreme Court held that when the marks at issue are not identical, actual dilution, as opposed to a likelihood of dilution, was the correct standard ${ }^{120}$ and implied that surveys may be required in future cases to establish actual dilution. ${ }^{121}$ The Court stated that "the mere fact that consumers mentally associate the junior user's mark with a famous mark is not sufficient to establish actionable dilution." 22

It took Congress a few years to act but act they did and definitively stamped out this interpretation of the Supreme Court. ${ }^{123}$ In the TDRA of 2006, Congress made the test "the likelihood of dilution" rather than "actual dilution." 124

As the data reported below makes clear, after Moseley and before the TDRA of 2006 (a period of three years), reported dilution cases in the United States dropped dramatically. There is no doubt that Moseley had the intended effect: courts should enjoin use of a trademark if there is some cognizable harm caused by dilutive conduct by a noncompetitor. As actual harm is impossible to show, trademark dilution claims dropped. ${ }^{25}$

In 2003 and 2004, Professor Smith and I (separately) argued for a "super registry" 126 for marks subject to trademark dilution protection. If we simply required registrants of claimed famous marks to make a second showing to the United States Patent and Trademark Office providing actual evidence of the mark's fame, this notice issue regarding what marks are protectable under dilution and what marks are not could be solved. This position has not been popular with trademark attorneys

Trademark Dilution Revision Act of 2006, Pub. L. No. 109-312, 120 Stat. 1730 (codified as amended in 15 U.S.C. \$\$ 1052, 1063, 1064, 1092, 1125. 1127 (2006)), aff $d .605$ F.3d 382 (6th (ir.)

119. Moseley v. V Secret Catalogue, Inc. 535 U.S. 985, rev'd and remanded by 537 U.S. 418 (2003)

120. The Court held such because the statute authorizes relief if a junior user "'canses dilution of the distinctive quality' of the [senior user's] mark." Moseler', 537 U.S. at 432-33 (quoting 15 U.S.C. $\$ 1125(\mathrm{c})(1)(2000$, amended 2012)). The statute does not say "likelihood of dilution," rather, the statute expressly says "causes dilution." See 15 U.S.C. \$1125(c)(1). As such, the Court found it necessary to show some objective evidence of dilution before relief was possible. See Moseley, 537 U.S. at $432-34$.

121. Moselev. 537 U.S. at 434.

122. Id. at 433 .

123. See Wong, supra note 53, at 63-66.

124. See id. at 64-66.

125. See infia notes $136-38$ and accompanying text.

126. See Lars S. Smith. Implementing a Registration System for Famous Trademarks, 93 TRADEmARK REP. 1097, 11 19-42 (2003); see also Kenneth L. Port. The Trademark Super Register: A Response 10 Professor Smith, 94 Trademark ReP. $881.888-90$ (2004). 
who make a living making spurious and good faith arguments that every mark is famous.

Congress passed the TDRA of 2006, overruling the most sensible trademark dilution judicial case to date. Now, the standard for determining if dilution has occurred is to look to the "likelihood of dilution." 27 Although there is nice symmetry here because it comports with the standard for trademark infringement of "likelihood of confusion," it further encourages speculation because it is unworkably vague. ${ }^{128}$

A likelihood of confusion is determined by looking at multiple, non-exhaustive factors that each circuit court has developed. ${ }^{129}$ These tests range from the specific to the broad, but they have been relied on for a long time to make reasonable estimations of when consumers presume that a good or service emanates from one entity when, in fact, it comes from a different entity, the "Law of the Profits" of trademark jurisprudence, as Learned Hand said. ${ }^{130}$ Specific, well-accepted elements of evidence can be relied upon in court to make out this claim. Surveys can be conducted. Direct testimony about when consumers are likely to be confused can be elucidated and articulated. Although, obviously also subject to the whims of client advocacy, surveys have the appearance of providing objective evidence of whether confusion is likely. Prospective in nature, the likelihood of confusion test has been a cornerstone of trademark jurisprudence for a long time.

It has turned out to be extremely complex and controversial to develop a reliable survey, adopted by courts, that tests whether a mark is diluted. ${ }^{131}$ After all, how could you ask an unsuspecting survey

127. See Trademark Dilution Revision Act of 2006, Pub. L. No. 109-312, 120 Stat. 1730, 1730-32 (codified as amended in 15 U.S.C. $\$ \$ 1052,1063,1064,1092,1125,1127$ (2006)).

128. Apparently, the TDRA is also vague as some courts still require a showing of actual dilution. See, e.g., Doctor's Data, Inc. v. Barrett, 170 F. Supp. 3d 1087, 1100 (N.D. Ill. 2016) ("To succeed on a trademark dilution claim, "proof of actual dilution is required, either through survey, financial, or circumstantial evidence." (citing Sullivan v. CBS Corp., 385 F.3d 772, 779 (7th Cir. 2004))).

129. For a full description of the tests the various circuit courts rely on to determine "likelihood of confusion," see SHELdoN W. HALPERN ET AL., Fundamentals of UNITED States INTEllectual Property LAW: Copyright, PATENT, AND Trademark 323-27 (5th ed. 2015).

130. See supra note 94 and accompanying text.

131. This has not stopped some from proposing some options of which, of course, the authors are quite confident. See, e.g., Cho, supra note 78, at 40-47; Magid et al., supra note 78, at 4, 26-38 ("[O]utlin[ing] a randomized experiment for proving actual dilution [and] conclud[ing] that the Court's legitimizing consumers' brand image through trademark dilution law is an important advancement in trademark protection."); see also Todd Anten, In Defense of Trademark Dilution Survevs: A Post-Moseley Proposal, 39 Colum. J.L. \& Soc. Probs. 1, $30-43$ (2005); William G. Barber, How to Do a Trademark Dilution Survey (or Perhaps How Not to Do One), 89 Trademark ReP. 616, 629-31 (1999); Krista F. Holt \& Scot A. Duvall, Chasing Moseley's Ghost: 
respondent if use of a famous mark by a non-related entity contributes to the winnowing away of the distinctive capacity of the famous mark? Wouldn't the survey taker need to educate the respondent about years of non-competing uses? Somehow, the respondent would, all on its own to avoid a leading question, have to say, "Wait, now the scales have been tipped and this use goes too far."

The United States courts had a difficult time accepting that trade dress claims were nothing more than trademarks for the shape of goods. If the test for trademark dilution is going to be a likelihood of dilution, where are the cases that should be filling in what in the world this means? If it is going to have symmetry with trademark infringement, we would logically expect courts to come up with specific, multi-factored, non-exhaustive lists for when a mark is diluted. This provides legitimacy for the courts. The court, in essence, pushed the analysis through the multi-factored test and comes up with a reasoned conclusion.

In the United States, the least sustainable judicial decision is an arbitrary one. ${ }^{132}$ Without a test for dilution, how is it that all determinations by courts are not simply arbitrary and, therefore, illegitimate?

Congress waded into this conversation when it mandated that the test in dilution cases be a "likelihood of dilution." 133 Congress abdicated its responsibility by not telling us what a "likelihood of dilution" means or how to test for it. And, of course, it would have if it could have. Given the nebulous nature of dilution itself, Congress apparently left for courts to fill in how to answer the ridiculous question of "likelihood of dilution." When Congress cannot explain when a mark is diluted and courts either cannot or will not, is it fair to maintain such a law? In addition, Congress is at complete odds with most academic commentary regarding dilution law. At best, Congress is not objective. Presumptively, academics are objective. The objective judgment of a vast majority of academics is that the dilution law ought to be repealed.

\section{DATA On Reported Dilution CASES}

As practitioners increasingly claim both trademark dilution and trademark infringement in the same case, it is becoming increasingly

\footnotetext{
Dilution Survels Uncler the Trademark Dilution Revision Act, 98 TRADEMARK Rl:P. 1311, 1322-44 (2008).

132. See Michael Pappas, Singled Out, 76 MD. L. Rev. 122, 141 (2016) ("An arbitrary law is illegitimate, even if it does not single out an individual, because the power of government does not extend to arbitrary actions.").

133. See Pub. L. 109-312, $\$ 2,120$ Stat. 1730, 1730-32 (2006) (codified as amended in 15 U.S.C. $\$ 1125(2006))$.
} 
difficult to collect reliable data on when dilution is the principle cause of action in any given case. Of course, practitioners are merely attempting to cover all of their bases and do not want to leave anything out for fear of appearing incompetent or, worse, being found liable for malpractice if they forget or exclude a viable cause of action. The problem is that trademark dilution jurisprudence is so fluid that it has become impossible for an average practitioner to determine when it applies and when it does not apply. Therefore, the dilution cause of action is added to complaints with no regard to whether there is competition and is most often pled on the same operative facts as the infringement cause of action.

In reality, if dilution adds anything to the plaintiff's case, it ought to be pled on separate facts. If the same operative facts are relied upon to plead a dilution cause of action as an infringement cause of action, it leaves commentators to wonder what was added with the FTDA. That is, if a court does not accept the plaintiff's claim to competition between the parties, the plaintiff can rely on the dilution cause of action regardless of competition and regardless of confusion. ${ }^{134}$ That was what the FTDA was supposed to add to trademark litigation. That practitioners are relying on the FTDA even when they have established competition and do not rely on separate operative facts indicates that they remain confused as to when and why the FTDA ought to apply.

That being the case, it is difficult to parse out the true dilution cases from the mix of the many cases that are actually infringement cases but where dilution is also claimed. By reading each case closely, one finds the following results — of all reported trademark cases ${ }^{135}$ between 1996 and 2015, the following number of reported cases included a dilution claim with a claim for infringement:

134. I5 U.S.C. $\$ 1125(\mathrm{c})(1)(2012)$ ("[T]he owner of a famous mark that is distinctive. . shall be entitled to an injunction against another person who .. commences use of a mark or trade name in commerce that is likely to cause dilution ... regardless of the presence or absence of actual or likely confusion, of competition, or of actual economic injury." (emphasis added)).

135. The Mitchell Hamline School of Law Trademark Litigations study consists of a list and a coding of all trademark cases that reached a dispositive result since July of 1947, the effective date of the Lanham Act. The study is accessible for free with no restrictions. See Trademark Litigation Search Results, WM. Mitchell C. L. INTELL. PrOP. INST., http:/app.mitchellhamline.edu/ Trademark/Home/TrdResults?Term=\&ddlYear=All+Years\&ddlCourt=All+Courts\&ddlBasis=3\&dd 1Spec=1 (last visited Feb. 15, 2018). As Mitchell Hamline School of Law supported this study, if you use it for any purpose, we only ask that attribution be given. Also, during this reported period, the total number of reported cases varied greatly but the average was about fifty cases per year. Data for the years 2012-2015 is on file with the author. 


$\begin{array}{lll}2015: 5 & 2008: 8 & 2001: 11 \\ 2014: 8 & 2007: 21 & 2000: 15 \\ 2013: 7 & 2006: 8 & 1999: 34 \\ 2012: 11 & 2005: 7 & 1998: 36 \\ 2011: 9 & 2004: 14 & 1997: 16 \\ 2010: 6 & 2003: 14 & 1996: 13^{136} \\ 2009: 15 & 2002: 21 & \end{array}$

This appears to be a fair amount of activity for the FTDA in reported trademark litigation in the United States; however, when the numbers are corrected for cases that rely exclusively on the FTDA, as the law was intended, the reported cases shrink to near zero as follows:

$\begin{array}{lll}\text { 1997: } 2 & 2004: 1 & 2011: 0 \\ 1998: 0 & 2005: 1 & 2012: 0 \\ 1999: 1 & 2006: 1 & 2013: 0 \\ 2000: 5 & 2007: 0 & 2014: 0 \\ 2001: 5 & 2008: 0 & 2015: 0^{137} \\ 2002: 5 & 2009: 0 & \\ 2003: 1 & 2010: 0 & \end{array}$

This data supports the conclusion that before the Moseley case, exclusive dilution cases were frequently reported, but since the Moseley case, even with the adoption of the TDRA, there are very few dilution cases that get reported. It may be that dilution does not occur as Paul Justin Heald and Bob Brauneis asserted ${ }^{138}$ or that dilution cases are no longer reported. The one thing that can be said with some certainty is that the FTDA is not seen as a judicial priority any longer. This, of course, begs the question of why it has fallen into disrepute or why judges do not mark dilution cases as "for publication." The answer to that conundrum is beyond the scope of this Article, but, in the vein of "I told you so," I suspect the judiciary is uncomfortable with the broad right granted by the FTDA, ${ }^{139}$ they do not understand it, ${ }^{140}$ or the cases

136. Id

137. Id. The study conducted at Mitchell Hamline School of Law covers years 1947-2011. Data for the years $2012-2015$ is on file with the author.

138. See Heald \& Brauneis, supra note 45, at 2561-62.

139. See Stephen G. Bullock, Proving a Claim Under the Federal Trademark Dilution ActAre the Courts Diluting the FTDA?, LOY. INTELL. PROP. \& HiGH TECH. J., Winter 2000, at 1, 4-5.

140. See Mead Data Cent., Inc. v. Toyota Motor Sales, U.S.A., Inc., 875 F.2d 1026, 1030-31 (2d Cir. 1989) (finding that the appropriate population for finding similarily is the reified TV announcer but the appropriate population to find fame is society at large). 
are not there to report. That is, dilution may be occurring but dilution cases are no longer being reported.

\section{THE COMMODIFICATION OF TRADEMARKS}

\section{A. Famous Marks}

When considering trademark dilution in the United States, one must differentiate between famous trademarks, iconic marks, and not famous trademarks. The FTDA is responsible for generating this distortion in trademark jurisprudence. When famous, ${ }^{141}$ the trademark holder may take advantage of the FTDA. ${ }^{142}$ If not, the trademark holder is not supposed to be able to rely on the FTDA, ${ }^{143}$ although advocates often make claims that any mark is famous. However, the concept of fame itself appears to be on a nebulous sliding scale where a mark can be famous and another mark can be really famous or iconic. When iconic, the distorted trademark jurisprudence becomes even more perverted. There are no provisions in the Lanham Act that address trademarks which become iconic.

GOOGLE is a good example of an iconic mark for which the rules of trademark doctrine change based on the iconic status of the mark. In Elliot v. Google Inc. ${ }^{144}$ the District Court in Arizona seemingly became star struck by the fame of the GOOGLE mark and, through tortured reasoning, found the mark GOOGLE not generic, not a verb, and a valid and enforceable mark, based on very little actual, non-opinion evidence. ${ }^{145}$ I am not making the foolish claim that the GOOGLE mark

141. As defined in the Lanham Act, "a mark is famous if it is widely recognized by the general consuming public of the United States as a designation of source of the goods or services of the mark's owner." 15 U.S.C. $\$ 1125(\mathrm{c})(2)(\mathrm{A})$ (2012). The Lanham Act goes on to give examples of evidence to be used to establish fame. Those examples include:

(i) The duration, extent, and geographic reach of advertising and publicity of the mark.

whether advertised or publicized by the owner or third parties.

(ii) The amount, volume, and geographic extent of sales of goods or services offered under the mark.

(iii) The extent of actual recognition of the mark.

(iv) Whether the mark was registered under the Act of March 3, 1881, or the Act of

February 20, 1905, or on the principal register.

Id. $\$ 1125(\mathrm{c})(2)(\mathrm{A})(\mathrm{i})-(\mathrm{iv})$.

142. Id. $\$ 1125(\mathrm{c})(1)$.

143. Id. (stating that the cause of action applies to "the owner of a famous mark").

144. 45 F. Supp. 3d 1156 (D. Ariz. 2014), aff'd, 860 F.3d $115 \mathrm{l}$ (9th Cir. 2017). For the purposes of how doctrine becomes fudged with the fame of the mark, focus is placed on the lower court opinion.

145. Id. at 1175 . 
is not iconic, just that the court in Elliot based its conclusion on rather suspicious reasoning.

Even though the GOOGLE mark is pronounced the same as the generic word "googol," which means 10 to the 100th power, GOOGLE has become an iconic search engine on the Internet. ${ }^{146}$ That is, the trademark GOOGLE was derived from the generic word, "googol."147 A simple misspelling of a generic word does not, normally, render it a distinctive trademark ${ }^{148}$ as the traditional doctrine in trademark law is once generic, always generic. ${ }^{149}$ As the sound, meaning, and appearance ${ }^{150}$ of "googol" became "google," it so resembled the generic word that it would have been difficult to argue that it was distinctive of that original word. In order to use a generic word arbitrarily and, therefore, create inherently distinctive trademark rights, the use would have to be distinctive of that word's original meaning. ${ }^{151}$ That is, GOOGLE would need to mean something other than a googol.

In fact, that is hard to imagine as Google Inc. presumptively set out to create a fast search engine with great capacity. That is, a search engine with googols of speed and capacity. As such, GOOGLE was never arbitrary. ${ }^{152}$ It was a suggestive mark. ${ }^{153}$ It suggested speed and capacity and the "imagination test" 154 would have been necessary to

146. See Frank Pasquale, Internet Nondiscrimination Principles: Commercial Ethics for Carriers and Search Engines, 2008 U. CHI. LEGAL F. 263, 263 n.1 ("Google is the most dominant search engine in the U.S. ...'); Google's Gag Order: An Internet Giant Threatens Free Speech, PERRSPECTIVES: BRINGING LIGHT TO DARKNESS (June 20, 2004), http:/www.perrspectives.com/ articles/art_gagorder01.htm (claiming that Google's iconic status leads to the appropriate use of the word as a verb and ignoring the trademark significance of this fact, and stating that "Google is on the verge of becoming the Internet arbiter of the First Amendment").

147. See Christina Sterbenz, Google Could Owe Its Name to a Simple Typo, Bus. INSIDER (Aug. 8, 2014, 2:45 PM), http:/www.businessinsider.com/how-did-google-gets-its-name-2014-8.

148. See J. THOMAS MCCARTHY, 2 MCCARTHY ON TRADEMARKS AND UNFAIR COMPETITION 12-138 (4th ed. 2011) ("[A] misspelling of a generic name which does not change the generic significance to the buyer, is still generic and cannot be a trademark.").

149. See Elliot v. Google Inc., 45 F. Supp. 3d 1156, 1161 (D. Ariz. 2014); TY Inc. v. Softbelly's, Inc., 353 F.3d 528, 531-32 (7th Cir. 2003).

150. The sound, meaning, and appearance of a mark is the generally accepted standard for determining if two marks are similar.

151. See Abercrombie \& Fitch Co. v. Hunting World, Inc., 537 F.2d 4, 8 (2d Cir. 1976) (discussing a secondary meaning of the word "Safari").

152. An arbitrary mark is a common English word used in such a different manner that it has nothing to do with the products on which is it used. An example is Apple brand computers. $C f$. id. at 9 n.6 ("'Ivory' would be generic when used to describe a product made from the tusks of elephants but arbitrary as applied to soap.").

153. A suggestive mark is one that suggests the quality or attribute of some good or service rather than be totally distinctive from source. See $i d$. at $10-11$.

154. See, e.g., Brother Records, Inc. v. Jardine, 318 F.3d 900, 905 n.1 (9th Cir. 2003); Interstellar Starship Servs., Ltd. v. Epix, Inc., 304 F.3d 936, 943 n.6 (9th Cir. 2002); ANNE GILSON LaLonde et al., 1 Gilson ON TRADEMARKS: Trademark Protection and Practice 2-100.1 
recognize that GOOGLE is a designated source, not simply claiming to be a fast search engine with large capacity.

Of course, GOOGLE has today become an iconic mark; however, at its inception Google Inc. merely used a misspelling of a generic word suggestively. As such, GOOGLE had inherent distinctiveness from the start. ${ }^{155}$ That is, Google Inc. began its masterful job of using and applying trademark jurisprudence to its advantage from the very beginning or manipulating it to serve its interests.

On July 8, 1998 when GOOGLE was in its infancy, Larry Page, one of the founders of GOOGLE said, "Have fun and keep googling."156 This is the type of generic use of the trademark by the claimant himself that would usually destroy trademark rights as it did for ASPIRIN ${ }^{157}$ and CELLOPHANE. ${ }^{158}$ To determine if the mark has become generic, courts look to the holder's usage to determine if the holder used it appropriately. ${ }^{159}$ That is, when there is evidence in the record that the very claimant of the mark used it as a generic word, courts will likely find the mark to be generic. ${ }^{160}$

The English language word "googol" still refers to 10 to the 100th power, no matter what Google Inc. does with the similar appellation. That is, there is also an inherent conflict in the law versus Google Inc. here, as the black letter law rule is that once generic, always generic. ${ }^{161}$ In the case of GOOGLE, it is not difficult to imagine, for example, a time when computer speed reaches a "googol." Every manufacturer of such a fast computer will have a competitive need ${ }^{162}$ to refer to her

\section{(2006).}

155. Cf. Cadbury Beverages, Inc. v. Cott Corp., 73 F.3d 474, 479 (2d Cir. 1996) ("Unlike a generic term, which can never be a valid trademark, or a descriptive term, which can be protected only if it has acquired 'secondary meaning,' a fanciful trademark 'is entitled to the most protection the Lanham Act can provide." (first citing McGregor-Doniger Inc. v. Drizzle Inc., 599 F.2d 1126, 1131 (2d Cir. 1979); and then quoting Lois Sportswear, U.S.A., Inc. v. Levi Strauss \& Co., 799 F.2d 867, 871 (2d Cir. 1986))).

156. Elliot v. Google Inc., 45 F. Supp. 3d 1156, 1171 (D. Ariz. 2014)

157. See Bayer Co. v. United Drug Co., 272 F. 505, 509-10, 513-16 (S.D.N.Y. 1921).

158. See Dupont Cellophane Co. v. Waxed Prods. Co., 85 F.2d 75, 80-82 (2d Cir. 1936).

159. See KP Permanent Make-Up, Inc. v. Lasting Impression I, Inc., 408 F.3d 596, 605-06 (9th Cir. 2005), cert. granted, 540 U.S. 1099 (2004), vacated and remanded, 543 U.S. 111 (2004), rev'd and remanded, 408 F.3d 596 (9th Cir. 2005); Am. Thermos Prods. Co. v. Aladdin Indus., Inc., 207 F. Supp. 9, 15-20, 25-28 (D. Conn. 1962), aff'd sub nom. King-Seeley Thermos Co. v. Aladdin Indus., Inc., 321 F.2d 577 (2d Cir. 1963), vacated, 418 F.2d 31 (2d Cir. 1969), modified, No. 7230, 1970 WL 197166 (D. Conn. Dec. 30, 1970).

160. See KP Permanent Make-Up, Inc., 408 F.3d at 605-06; Am. Thermos Prods. Co., 207 F. Supp. at $15-20,25-28$

161. See Keebler Co. v. Rovira Biscuit Corp., 624 F.2d 366, 374 (1st Cir. 1980) ("N]o amount of purported proof that a generic term has acquired a secondary meaning associating it with a particular producer can transform that term into a registrable trademark.").

162. See A.J. Canfield Co. v. Honickman, 808 F.2d 291, 304-06 (3d Cir. 1986) (citing CES 
computer as one that works at a "googol pace," or some such reference. This such reference, although currently a nominative fair use under trademark doctrine, ${ }^{163}$ may be perceived as dilutive conduct by Google Inc. in the future and they may attempt to foreclose such use.

However, the court in Elliot never mentioned the generic word "googol." In a case challenging the trademark GOOGLE for being generic, it seems disingenuous to never mention the generic word "googol." After all, once googol was generic, it is supposed to always be generic, or so the black letter law doctrine informs us. ${ }^{164}$ If two marks sound, mean, or appear the same, trademark doctrine would consider them the same. ${ }^{165}$ Therefore, the mere misspelling of GOOGLE from googol is irrelevant to this analysis.

In Elliot, the court analyzed the phrase "go google it" and attempted to determine if use of "google" as a verb was generic simply because it was used as a verb as Elliot claimed. ${ }^{166}$ The court came to the conclusion that "go google it" can be both an indiscriminate verb usage and a discriminate verb usage. ${ }^{167}$ Indiscriminate verb use, the court stated, is where the purchaser does not care from where the good or service emanates. ${ }^{168}$ Discriminate use amounts to the use of a trademark as a verb but the consumer still cares from where the goods or services emanate. $^{169}$

The court appropriately stated that the statutory standard is for it to determine the "primary significance" of the mark. ${ }^{170}$ If the mark primarily indicates the product, the mark is generic; if the mark primarily indicates the producer, it is a valid trademark. ${ }^{171}$ Purchaser motivation is expressly not the test of genericism under the Lanham Act. ${ }^{172}$ The courts are not to look at why someone bought the good or

Publ'g Corp. v. St. Regis Publ'ns, Inc., 531 F.2d 11, 15 (2d Cir. 1975)).

163. See Brother Records. Inc. v. Jardine, 318 F.3d 900, 903-05 (9th Cir. 2003); Playboy Enters. v. Welles, 279 F.3d 796, 806 (9th Cir. 2002) ("For the same reason uses in comparative advertising are excepted from anti-dilution law, we conclude that nominative uses are also excepted. A nominative use, by definition, refers to the trademark holder's product. It does not create an improper association in consumers' minds between a new product and the trademark holder's mark.“), aff'd, 30 Fed. App'x. 734 (9th Cir. 2002).

164. But see Deven R. Desai \& Sandra L. Rierson, Confronting the Genericism Conundrum, 28 CARDOZO L. REV. 1789, 1830-33 (2007) (arguing that the "once generic, always generic" principle has done trademark doctrine and the economy a disservice).

165. See Henri's Food Prods. Co. v. Kraft, Inc., 717 F.2d 352, 354-56 (7th Cir. 1983).

166. Elliot v. Google Ine., 45 F. Supp. 3d 1156, 1165, 1173-75 (D. Ariz. 2014).

167. Id. at 1161-62, 1165, 1175 .

168. See id at 1162 .

169. Seeid.

170. Id. at 1163 (quoting Kellogg Co. v. Nat'l Biscuit Co., 305 U.S. 111,138 (1938)).

171. Id. at 1161 (quoting 15 U.S.C. $\$ 1064(3)(2012)$ )

172. 15 U.S.C. $\$ 1064(3)$. 
service, they are supposed to look to see what the primary significance of the mark was to them when confronted with the mark. A consumer only needs to know that the mark identifies a consistent source. ${ }^{173}$ The consumer does not need to know or "care" what the source is. The court's two-step dance around discriminate and indiscriminate verb usage is merely another way of inquiring and relying upon customer motivation.

Factors to be considered when determining if a trademark is generic include the "(1) competitors' use of the mark, (2) plaintiff's use of the mark, (3) dictionary definitions, (4) media usage, (5) testimony of persons in the trade, and (6) consumer surveys." 174 However, because the court viewed this test through the lens of discriminate/indiscriminate verb usage, its conclusions apply to purchaser motivation, not the primary significance of the mark. There is a long line of cases ${ }^{175}$ and an express amendment ${ }^{176}$ to the Lanham Act that dismiss purchaser motivation as a relevant element when a court analyzes a mark for genericism. As it is not likely that the court in Elliot was unaware of this case law and amendment to the Lanham Act, it begs the question of what motivated the court to find the legal realism ${ }^{177}$ result of appearing to know the outcome (GOOGLE is not generic) and then fashioning the outcome to match that expectation.

The evidence relied upon by the court in Elliot was not the most compelling. Regarding the element of dictionary definitions, the court did find in favor of Elliot by concluding that in dictionaries, even if they are heavily influenced by Google Inc., "the word google carries meaning as an indiscriminate verb." 178 In other words, the court in Elliot found the dictionary definitions to lend itself to a finding that the GOOGLE mark was generic.

In doing so, the court relied on current dictionary references, which have largely been influenced by Google Inc. ${ }^{179}$ As such, these references are not reliable. The court points out that all cited dictionary references

173. Klieger, supra note 2, at 790 ("Where, as is often the case today, consumers do not know or even care to know the exact origin of goods or services bearing a particular trademark, trademarks serve as markers of consistent source and quality.").

174. Am. Online, Inc. v. AT \& T Corp., 64 F. Supp. 2d 549, 563-64 (E.D. Va. 1999), aff'd in part, vacated in part, 243 F.3d 812 (4th Cir. 2001). The court in Elliot appropriately considered these factors. See Elliot, 45 F. Supp. 3d at 1170-73.

175. See, e.g., Anti-Monopoly, Inc. v. Gen. Mills Fun Grp., Inc., 684 F.2d 1316, 1324-26 (9th Cir. 1982).

176. Trademark Law Revision Act of 1988, Pub. L. No. 100-667, sec. 115, \$114, 102 Stat. 3935, 3940-41 (codified as amended in scattered sections of 15 U.S.C.).

177. See Jerome Frank, LAW AND THE MOdERN Mind 42-47 (1930).

178. Elliot, 45 F. Supp. 3d at 1171.

179. Id. 
include a reference of google as the name of a search engine. ${ }^{180}$ Regarding Elliot's claims that Google Inc. influenced the dictionary entries, the court gratuitously called such claims "scurrilous attacks unsupported by admissible evidence."181 Google Inc.'s enforcement efforts in this regard are quite well-known in the industry. ${ }^{182}$ This conduct by Google Inc. is so pervasive that a court might even take judicial notice of it happening and not require admissible evidence, it is odd for the court to go so far as to label such obvious conduct as a "scurrilous attack." 183 After all, the dictionary meaning of "scurrilous" is "making or spreading scandalous claims about someone with the intention of damaging their reputation." 184 To call Elliot's assertion that Google Inc. is obviously influencing the dictionary definition of "google" "scurrilous" is to demonstrate the court's bias in Google Inc.'s favor. That is, GOOGLE is too big to fail.

However, regarding the claimant's use of the mark, the court was apparently confused or misled. This element should be focused on how the claimant itself used the mark. ${ }^{185}$ The point, of course, is that it would be unreasonable to sustain a trademark if the holder of the mark itself failed to use the mark as a mark. The court skipped this important detail and jumped to whether the non-enforcement of a mark renders it generic. ${ }^{186}$ Of course, if unreasonably lacking in enforcement, ${ }^{187}$ a court might find the mark generic; ${ }^{188}$ however, that does not mean the holder's use of the mark should be ignored as the court did. There is good

180. $I d$.

181. Id. at $1171 \mathrm{n} .9$.

182. See David A. Vise \& Mark Malseed, The GoOgle Story: For Google's 10Th BIRTHDAY 220-27 (updated ed. 2008).

183. See Elliot, 45 F. Supp. 3d at $117 !$ n.9.

184. Scurrilous, ENG. OXFORD LIVING DICTIONARIES, https:/en.oxforddictionaries.com/ definition/scurrilous (last updated Jan. 1, 2017).

185. See Filipino Yellow Pages, Inc. v. Asian Journal Publ'ns Inc., 198 F.3d 1143, 1150-51 (9th Cir. 1999); Surgicenters of Am., Inc. v. Med. Dental Surgeries, Co., 601 F.2d 1011, 1013 n.5 (9th Cir. 1979) ("If the plaintiffs used the mark from the very beginning in a way that the public connected the term with the service rather than with the server, then they have contributed to the genericness of the term.").

186. Elliot, 45 F. Supp. 3 d at 1171.

187. See Polaroid Corp. v. Polarad Elecs. Corp., 287 F.2d 492, 496-98 (2d Cir. 1961). Note that the concept of "policing a mark" stems from dicta in Polaroid. Polaroid requires only that trademark holders be reasonable in policing their marks. It does not require them to stamp out (by filing a law suit) every single use of every single potentially infringing use.

188. See Am. Online, Inc. v. AT \& T Corp., 243 F.3d 812, 823 (4th Cir. 2001) ("You Have Mail' has been and continues to be used by AOL and by others to alert online subscribers that there is electronic e-mail in their electronic mailboxes, and no more. This functional use of words within the heartland of their ordinary meaning cannot give rise to a trademark for the e-mail service when it is no more than the announcement of the arrival of a message."). 
evidence in the record ${ }^{189}$ that might lead a court to conclude that the mark was used generically by the holder and, as such, a court might be justified in finding GOOGLE to be generic. The court merely skipped this analysis.

Regarding the media usage of the mark GOOGLE, the court made an odd presumption that the media never refers to an Internet "search engine as a "google," and, therefore, the media usage does not indicate the mark has become generic. ${ }^{190}$ This statement, however, is inconsistent with the evidence presented to the court. For a court that is obsessed with finding discriminate or indiscriminate verb usage of the mark and presumes that the answer to this question will lead it to the promise land of a determination of genericism, the court now shifts to thinking about the mark as a noun, with absolutely no indication that it has done so. For this element for this court, the mark GOOGLE would be found generic if it had become the noun for Internet search engines. As this is a new twist to this case, there appears to be no effort made by Elliot to determine if it is now a noun or not. This is a further indication that the court's focus on grammar can only show purchaser motivation, not the primary significance of the mark.

In what may have appeared to be a mundane case to the court about a remarkably famous trademark versus a cybersquatter, much more is actually at stake. Because the court seemed to be overly impressed with the fame of the GOOGLE mark or because Elliot relied nearly exclusively on the argument that using a mark as a verb always renders the mark generic, the court got sloppy. The court appeared convinced that the distinction between discriminate and indiscriminate verb usage was a distinction with a difference when analyzing when a trademark has become or was generic. Again, this false distinction created the impression for the court that one (discriminate) verb use acted like trademark use and the other (indiscriminate) use did not. This false distinction masks the actual role of the court in such an analysis. The actual role of the court is to determine the primary significance of the mark, not the purpose behind the use of the mark as a verb or, its equivalent, purchaser motivation. And, maybe more telling, is the fact that the court seems to have ignored GOOGLE as a noun. If a trademark becomes any part of speech, its primary significance is arguably no longer to act as a mark but, instead, to act as a generic English language word.

189. Larry Page, one of the founders of GOOGLE said, "Have fun and keep googling." Elliot, 45 F. Supp. 3d at 1171.

190. Id at $1172-73$. 
This masking becomes possible when GOOGLE is iconic. When famous and iconic, the court seems to have put its responsibility aside and, in true legal realism terms, knew what result it needed to arrive at and arrived at that result. GOOGLE was famous and iconic, not generic and invalid.

The point of this analysis is not to attempt to show that GOOGLE is generic or that the court came to the normatively wrong conclusion. The point of this analysis is to demonstrate how the fame of the GOOGLE mark misdirected the court's analysis. The fame of the mark, in fact, overshadowed the analysis. That is, fame continues to cause problems for United States' trademark jurisprudence. This is the very same fame that it codified in the FTDA. Naturally, there are stronger trademarks and weaker trademarks; however, when the fame of the mark becomes the driving purpose of the mark, not the mark's capacity to identify source, we forget the actual purpose of trademark jurisprudence. The source indicating function of the trademark has always been paramount. When fame takes over, the mark becomes a commodity and fame becomes the goal as, when famous, the rules change. When famous (and iconic), the rules change as was made apparent in Elliot.

If, for the sake of argument, we do not accept the court's perverted analysis regarding the discriminate/indiscriminate verb usage, Elliot does seem to have some cognizable interests or, at least, some very good arguments to be made. The first is that GOOGLE is derived from the word "googol," a generic word. Any analysis has to overcome this fact. It can be overcome by Google Inc. demonstrating that GOOGLE was inherently distinctive as a suggestive mark and, in addition, has acquired a remarkable amount of secondary meaning; however, the further black letter law of genericism is that no amount of secondary meaning will save a mark from genericisim. ${ }^{191}$ Likewise, no matter how inherently distinctive the mark is from the outset, generic use by the proponent of the mark would usually result in a finding of genericism. ${ }^{192}$ Google Inc. seems to be guilty all along of generic use of GOOGLE. This may be another place where the iconic nature of the mark trumps historical doctrine or, at least, works to mask it and mislead the court.

191. See Microsoft Corp. v. Lindows.com Inc., 64 U.S.P.Q.2d 1397, 1409 (W.D. Wash. 2002) (" $[\mathrm{N}]$ o degree of secondary meaning will save a generic mark.").

192. See King-Seeley Thermos Co. v. Aladdin Indus., Inc., 321 F.2d 577, 579 (2d Cir. 1963), vacated, 418 F.2d 31 (2d Cir. 1969), modified, No. 7230, 1970 WL 197166 (D. Conn. Dec. 30, 1970); Pilates, Inc. v. Current Concepts, Inc., 120 F. Supp. 2d 286, 299 (S.D.N.Y. 2000) ("A plaintiff's own generic use of its marks supports a finding of genericness, as does generic use by plaintiff"s claimed predecessors."). 
The record is replete with examples of companies using trademarks inappropriately and then losing trademark rights to a finding of genericism or successfully wrestling the trademark back from the brink of a genericism finding. ${ }^{193}$ That is, it is the use of the trademark that is usually analyzed in a trademark genericism challenge as it is always the significance to the consuming public that should be the focus of the analysis, not some trumped up redefinition of the dual roles that verbs might play in the English language just to save an iconic mark from a finding of genericism.

Of course, it is difficult to imagine the GOOGLE mark as generic. Google Inc. has, of course, invested much time, money, and energy in succeeding to create an iconic brand. It is hard to imagine a court coming to the conclusion that GOOGLE was generic. The point here is not necessarily to argue that GOOGLE is generic but only that the court in Elliot failed to do its job in analyzing the primary significance of the mark, got caught up in the fame of the mark, and came to the conclusion that purchaser motivation in the discriminate use of the verb "go google it" was the appropriate analysis. That is, the court's "discriminate verb usage" is nothing different than purchaser motivation. When dealing with a famous, iconic mark like GOOGLE, it is demonstratively quite easy for the court to be led astray in its analysis. The court had an outcome it desired to reach and it reached that outcome. Although the court appropriately stated that the primary significance of the mark was the test to determine genericism, it utterly failed in any attempt to actually apply that test.

The court in Elliot ${ }^{194}$ did actually attempt to sort through the various types of other evidence that might educate it about the primary significance of the mark by looking at "dictionary usage; mark-holder usage; competitor usage; media usage; and consumer surveys."195

Many other such iconic trademarks in the United States have this type of star power; however, if not famous, the generic use of the mark as a verb usually destroys trademark significance when it is done by the trademark claimant or by purchasers. ${ }^{196}$ It seems that, again, it is the mere fame of the mark which dictates a different analysis. Once famous,

193. See List of Generic and Genericized Trademarks, WIKIPEDIA, https://en.wikipedia.org/ wiki/List_of_generic_and_genericized_trademarks (last visited Feb. 15, 2018).

194. Although trademark dilution was claimed in Elliot, the court focused on the claim of genericism, as the motion before it was to cancel the trademark GOOGLE, and so it did not reach a determination of the dilution claim. See Elliot, 45 F. Supp. 3d at 1160,1175

195. Id. at $1170-73$.

196. But see Microsoft Wants You to 'Verb Up' and 'Bing It', GAWker (May 29, 2009, 12:36 AM), http://gawker.com/5272444/microsoft-wants-you-to-verb-up-and-bing-it (arguing that more iconic marks are intentionally being used as verbs). 
trademarks get treated differently in the United States. This might be good and appropriate; however, nowhere in the Lanham Act other than the FTDA does it state that famous marks should be treated differently than non-famous marks. The FTDA leads courts to a trifurcation of the concept of fame: (1) non-famous marks; (2) famous marks; and (3) iconic marks. Iconic marks operate like a magnet to lead courts astray of standard trademark jurisprudence.

This jurisprudence has been perverted by the FTDA. Attempting to make a mark famous or iconic acts to commodify the mark so that holders pursue the hypothecation value of a so-called famous mark rather than the remarkable ability of such marks to identify source.

\section{B. Non-Famous Marks}

The commodification of iconic trademarks in the United States too often affects non-famous marks as well. Holders of non-famous and non-iconic trademarks desire to move their trademarks from this "non" status to a more powerful position - a position of fame. In order to accomplish this objective, trademarks in the "non" category are treated by their holders as if they were famous. ${ }^{197}$ As the concept of fame is so nebulous under United States law, creative attorneys make creative arguments to accomplish this task. These creative attorneys are encouraged to make creative arguments in the zealous representation of their clients' (what they perceive as) best interest. That is, even weak and descriptive marks are often times claimed to be famous by creative trademark counsel. ${ }^{198}$

There is no downside to this type of speculation. ${ }^{199}$ Through aggressive litigation tactics where trademark holders claim their marks were subject to dilution from non-competing entities, as these noncompeting entities acquiesced to these sometimes spurious claims, the scope of the claimed trademark grows. At some also nebulous point, these non-famous trademarks become subject to claims that they have become famous and all non-competitive use can be enjoined pursuant to the FTDA. ${ }^{200}$ This is the gold-standard in trademark discourse. Savvy

197. See infra notes 200-09 and accompanying text.

198. See infra notes 200-09 and accompanying text.

199. In $5.5 \%$ of all reported trademark cases over the last decade, the defendant prevailed on its motion for summary judgment, a significantly higher percentage than in all litigation. Port, stura note 22, at 225-27, 231-32. However, in those cases where the defendant prevailed in its motion for summary judgment, Rule 11 sanctions were never found against the non-moving plaintiff. Id. at 232; see FED. R. CIV. P. 11. That is, plaintiffs are free to claim whatever they want, whether a reasonable claim or unreasonable under Rule 11 jurisprudence and never suffer any consequences.

200. 15 U.S.C. $\$ 1125(\mathrm{c})(1)(2012)$. 
trademark holders work to make the mark famous and then, using the FTDA, shut down all non-competing uses. To the extent non-competing uses are eliminated, the hypothecated value of the trademark increases, which only further fuels speculation in the trademark.

Trademark counsel are free to claim any mark is famous and diluted. ${ }^{201}$ There is no check to this conduct. Third-party users, noncompetitors, and anyone interested in the use of the same or similar mark on unrelated goods and services, are often left in a difficult situation. They have no notice that someone might be making the (sometimes spurious) claim that the non-famous trademark was diluted. Trademark counsel can only search available databases and make gallant, if subjective, suppositions about whether a listed registered trademark has reached the requisite level of fame to trigger the FTDA. For better or worse, the issue of fame is left to the persuasive powers of each trademark attorney arguing each trademark matter.

All current incentives in United States trademark law are to claim a mark is famous as early as possible and, sometimes as cited above, in rather dubious circumstances. The commodification of the mark occurs when the motivation for protecting a mark switches from protecting the mark's source identification function to seeing the trademark as a financial asset where preventing all non-competing uses for a famous or non-famous mark furthers the hypothecation value of the trademark. To

201. See, e.g. Genovese Drug Stores, Inc. v. TGC Stores, Inc., 939 F. Supp. 340, 343, 350 (D.N.J. 1996) (holding that "We'll Take Good Care of You" is not famous, despite attomey"s claim to the contrary). The court got part of this analysis right and raises the question of what counsel was thinking of to make the claim:

[T] his Court finds that plaintiff's mark is not famous and unworthy of protection under the new federal law. The slogan has only been used by plaintiff for nine years. Also plaintiff only uses the slogan in association with the store name Genovese. Therefore, in and of itself. the slogan is not inherently distinctive. Defendant is not employing plaintiff"s mark by using the words "take good care." Moreover, as discussed above, the parties are not in direct competition. Hence, the Court finds that plaintiff is unlikely to succeed on the merits of its dilution claims.

Id. (citations omitted). Of course, if the parties are not in direct competition, this case is most appropriately a dilution case, not exempted from dilution as the court seems to think. See, e.g., ArcSoft. Inc. v. Cyberlink Corp.. 153 F. Supp. 3d 1057, 1067 (N.D. Cal. 2015) ("Given the high burden that a plaintiff faces in establishing that its mark is sufficiently famous to support a dilution claim, ArcSoft must plead more than conclusory assertions of fame to survive a motion to dismiss: it must plead facts that support a plausible inference that its [Perfect365] mark qualified as a household name by February 2014 (or whatever date is alleged as defendants" first use of the Infringing Marks). Because Arcsoft has not done so, the motion to dismiss the fourth and sixth causes of action for trademark dilution is GRANTED WITH LEAVE TO AMEND."); New World Sols., Inc. v. NameMedia Inc., 150 F. Supp. 3d 287, 323 (S.D.N.Y. 2015) ("Because there is no genuine dispute of material fact, then, that the Mark was not famous for purposes of the federal dilution claim when NameMedia registered the Domain Name, Defendant's Summary Judgment Motion on this claim is granted."); Kuklachev v. Gelfman, 600 F. Supp. 2d 437, 472 (E.D.N.Y. 2009) ("Furthermore, there is no evidence to indicate that the 'Moscow Cats Theatre' mark is 'truly famous.' The motion to dismiss Claim IV of the complaint is granted."). 
be sure, there are many instances where trademarks reach some requisite level of "fame" (such as GOOGLE) regardless of how fame is defined and applied. However, most trademarks are not objectively famous. Most trademarks are just trademarks with no iconic value. When counsel for even these non-famous, non-iconic trademarks claim that the trademark is famous, even non-famous marks are being used as a commodity, not as a source identifier.

Non-famous trademarks are not without a remedy for infringement. Non-famous trademarks can, and always do, rely on section 32 of the Lanham $\mathrm{Act}^{202}$ to claim the trademark was infringed by a competitor using the same or similar mark on the same or similar goods. ${ }^{203}$ As stated above, trademark dilution and trademark infringement are two mutually exclusive concepts. ${ }^{204}$ Although this, too, has been perverted by zealous advocates for trademark holders where simply every conceivable cause of action is just tossed into a complaint without sufficient consideration, the original intent of the FTDA was to provide a cause of action where an alleged "gap" 205 in existing protection. If trademark dilution is coterminous with trademark infringement, after all, dilution provides nothing that infringement does not and, therefore, has become irrelevant.

Plaintiffs no longer feel confident enough of an exclusively dilution cause of action even if that is the true harm it is recognizing. Rather, dilution only comes up today as an add-on cause of action to an infringement claim. ${ }^{206}$ At best, again through the appropriate and zealous advocacy of trademark litigators, the bright line that used to exist between dilution and infringement has become blurred to the point of non-recognition.

Non-famous marks, therefore, are claimed to be famous for sometimes spurious reasons to increase the perceived value of the trademark. Trademark holders are encouraged to engage in this speculation because the broader use is acquiesced to, the more the trademark is worth in hypothecation, and the more reward it recognizes

202. Lanham (Trademark) Act, Pub. L. No. 79-489, 60 Stat. 427, 437-38, \$32 (1946) (codified at 15 U.S.C. $\$ 1114(1946))$.

203. See, e.g., Soloflex Inc. v. Nordictrack lnc., 31 U.S.P.Q.2d 1721, 1728-30 (D. Or. 1994).

204. See supra Parts IV-V.

205. See supra note 14 and accompanying text.

206. See LALONDE ET AL., supra note 10, at 5-A7 to -A8 ("[W]here there is a clear case of infringement on competing soft drinks or computers, a fortiori the distinctiveness of the famous mark would be diluted. Accordingly, one would expect to see violations of both sections of the Act pleaded in a complaint asserting rights in even an arguably famous trademark. Cases where there would be dilution only, and no infringement, are few and far between. These might involve famous trademarks for industrial products sold to sophisticated consumers ...."). 
from this speculation. Moving a trademark from a weak mark to a famous mark has many rewards. Not only can the holder of a weak mark that potentially becomes famous due to the acquiescence of others and, thereby, is enforced in an increasingly broader scope, but also the underlying value of the mark increases. That is, the basic objective of holders of non-famous marks is to increase the hypothecation value of the underlying mark, not to protect the mark's source identifying function.

This increase in hypothecation value becomes possible when the speculation in a mark's fame happens. This speculation is fueled by the bifurcated values attached to famous and non-famous marks. Quite naturally, famous marks are and should be granted broader enforcement rights when legitimately infringed. This has always been the trademark doctrine in the United States. ${ }^{207}$ However, quite unnaturally, when nonfamous marks are claimed to be famous just to speculate and increase the hypothecation value of the mark rather than identify source, trademarks are being used as a commodity and bought, sold, and traded irrespective of the "goodwill appurtenant thereto." 208 It is the goodwill appurtenant thereto to which trademark jurisprudence applies. Trademark speculation of non-famous marks is a new addition to trademark claimants' motivations.

\section{CONCLUSION}

The FTDA and related TDRA should be repealed. Each has encouraged a new form of trademark speculation that used to be referred to as "trademark extortion" or "trademark bullying." This new form of trademark speculation converts the trademark itself into a commodity, which can be bought, sold, and invested in devoid of the goodwill with which it is used. Trademark rights in the United States must be used on or in association with some good or service. There are no trademark rights in gross. The FTDA creates these trademark rights in gross and that allows the trademark to be perceived by its holders as a commodity. Worse yet, holders of non-famous trademarks, trademarks that should

207. See Rierson, supra note 45 , at 305 ("If dilution law is forced to justify its own existence on traditional trademark (i.e., economic) grounds, it almost certainly is a loser. The benefits gained by dilution enforcement, which are slim at best, are outweighed by the attendant costs, including those that are occasioned by the inevitable overreaching that it enables. If the holder of a famous trademark is injured by another's use of its mark, trademark infringement law, particularly in the breadth of its modern application, should be more than adequate to prevent real economic injury. Even in trademark infringement cases, the famous trademark holder can obtain injunctive relief without proving anything beyond a likelihood of confusion; harm is presumed.").

208. See supra note 42 and accompanying text. 
not be taking advantage of the FTDA, become incentivized to become labeled "famous" and take advantage of the FTDA just to expand the scope of the trademarks and, in the process, convert even non-famous, non-iconic, regular trademarks into assets or commodities which can be hypothecated devoid of the source identifying function that the courts and the Lanham Act envisioned.

When trademarks become commodities, we lose focus on the point of trademark law. In the end, trademark law is a consumer protection statute in the United States. It is intended to prevent consumers from being deceived as to the source or origin of a good or service. When we treat trademarks as commodities, we lose sight of the original purpose of trademark law. Trademark law stops being a consumer protection statute that is needed to keep transaction costs as low as possible so that purchasers pay the least possible for their goods or services, to a law by, for and with, trademark holders. For any healthy trademark system, there needs to be a balance between the trademark holder, consumers, and third parties. We need the trademark holder to invest in trademarks to reduce search costs; we need consumers to trust the system and make accurate purchases where they get what they wanted; we need third parties to be protected so that they will enter the market and we will have a healthy competitive economic environment.

When we commodify trademarks, the trademark holder wins this fight. We only look to the interests of the trademark holder and forget the needs of the consumer and the needs of third parties. When GOOGLE becomes too strong to fail, healthy trademark discourse is lost. 


\title{
Mitchell Hamline Open Access
}

Mitchell Hamline Open Access is the digital archive of Mitchell Hamline School of Law. Its mission is to preserve and provide access to our scholarly activities, for the benefit of researchers and members of the legal community.

Mitchell Hamline Open Access is a service of the Warren E. Burger Library.

open.mitchellhamline.edu

\author{
$\mathrm{MH}$ \\ MITCHELL | HAMLINE \\ School of Law \\ (C) Mitchell Hamline School of Law \\ 875 Summit Avenue, Saint Paul, MN 55105 \\ mitchellhamline.edu
}

